\title{
The Pursuit of ES Cell Lines of Domesticated Ungulates
}

\author{
Neil C. Talbot $\cdot$ Le Ann Blomberg
}

Published online: 9 July 2008

(C) Humana Press 2008

\begin{abstract}
In contrast to differentiated cells, embryonic stem cells (ESC) maintain an undifferentiated state, have the ability to self-renew, and exhibit pluripotency, i.e., they can give rise to most if not all somatic cell types and to the germ cells, egg and sperm. These characteristics make ES cell lines important resources for the advancement of human regenerative medicine, and, if established for domesticated ungulates, would help make possible the improvement of farm animals through their contribution to genetic engineering technology. Combining other genetic engineering technologies, such as somatic cell nuclear transfer with ESC technology may result in synergistic gains in the ability to precisely make and study genetic alterations in mammals. Unfortunately, despite significant advances in our understanding of human and mouse ESC, the derivation of ES cell lines from ungulate species has been unsuccessful. This may result from a lack of understanding of species-specific mechanisms that promote or influence cell pluripotency. Thorough molecular characterizations, including the elucidation of stem cell "marker" signaling cascade hierarchy, species-appropriate pluripotency markers, and pluripotency-associated chromatin alterations in the genomes of ungulate species, should improve the chances of developing efficient, reproducible technologies for the establishment of ES cell lines of
\end{abstract}

Mention of a trade name, proprietary product or vendor does not constitute a guarantee or warranty of the product by USDA or imply its approval to the exclusion of other suitable products or vendors.

N. C. Talbot $\cdot$ L. A. Blomberg $(\square)$

Animal Biosciences and Biotechnology Laboratory,

ANRI, ARS, USDA,

BARC-East, Bldg. 200, Rm. 22,

Beltsville, MD 20705, USA

e-mail: LeAnn.Blomberg@ars.usda.gov economically important species like the pig, cow, goat, sheep and horse.

Keywords ESC · Pluripotency - Ungulate - Differentiation . Inner cell mass $\cdot$ Epiblast

\section{Introduction}

Embryonic stem (ES) cells (ESC), pluripotent cells with the capacity for long-term propagation and broad differentiation plasticity, were first established as cell lines from the inner cell mass (ICM) of mouse blastocysts over two decades ago [1]. These cells have a unique functional feature in that upon combination with a host embryo (chimera production) they can contribute to all tissues and organs, including germ cells, of the resulting chimeric mouse. As these cells are competent to form all cell types, including extraembryonic placental tissues, they are considered totipotent or pluripotent depending on the particular cell line or environmental context. Furthermore, they can be clonally propagated and maintained in culture indefinitely. These characteristics have made them an invaluable genetic engineering tool for studying functional mammalian genetics, mammalian developmental biology, and for producing animal models of human diseases.

The establishment of ES cell lines of domesticated ungulates, e.g., the pig, sheep, goat, cow or horse, is of interest for similar reasons to those of mouse and human ES cell lines. These reasons include basic research interests such as comparative embryology and the cell biology of ungulate stem cell maintenance and differentiation. Also, several applied research initiatives await the establishment of ungulate ES cell lines. These include, for example, the creation of models of human genetic diseases and cell 
transplantation therapies. Another significant utility of ES cell lines of domesticated ungulates is their potential use for the precise genetic engineering of these farm animals to improve their production traits, derived products, resistance to disease, and "biopharming". These research and development goals could be accomplished through ESC chimera technology, already well established in producing genetically modified mice [2], or by improving the efficiency of somatic cell nuclear transfer technology that is currently used as a means of genetically engineering ungulates [3]. The immediate problem for the scientific aspirations mentioned above, and one of the primary subjects of this review, is that no "proven" ungulate ES cell lines currently exist despite the many peer-reviewed journal articles describing ungulate ES or ES-like cell lines over the past 18 years.

The isolation and culture properties of the ungulate blastocyst's epiblast tissue, and its extraembryonic tissues, trophectoderm and yolk-sac endoderm, will be discussed below. A great deal is known about the cell culture characteristics and molecular biology of the ESC of the mouse, monkey, and human. Therefore, this body of information will be reviewed for comparison to what has been reported for ungulate blastocysts and epiblast tissue, and it may serve as a guide for setting priorities for future investigations of ungulate ESC biology. For example, the various molecular markers that are used to define mouse and primate ES cell lines will be reviewed and their adequacy for the analysis of ungulate ES cells will be examined. Finally, potential future approaches for the establishment of ungulate ES cell lines and their prospects for success will be considered.

\section{Review of Ungulate ES Cell Line Literature}

Over the past 18 years many reports of porcine, bovine, caprine, ovine, and equine ES cell lines, or what are often presented as "ES-like" cell lines, have been published. This reflects the on-going interest in isolating ungulate ES cell lines for the study of animal developmental biology, for genetic engineering applications to rapidly improve farm animal traits and create new biotechnologies (bio-pharming), and for establishing animal models applicable to various human diseases, physiological processes, and pharmacokinetic studies. Unfortunately, none of the ungulate cell cultures or cell lines so far described have been definitively proven to be ES cells, and, to our knowledge, none have been successfully used as biological reagents in a manner similar to that of human, monkey, or mouse ES cells, i.e., directed pluripotent in vitro differentiation $[4,5]$ or as a means of genetically engineering a mammal through embryonic chimera formation [2].
The early preimplantation embryo is the source of cells that has been used for the derivation of ES cell lines. The primordial germ cells (PGC) residing in the early genital ridge are another source of cell lines with similar properties, but PGC-derived ES cell lines, so-called EG cell lines, will not be reviewed here. Two to 3 days after fertilization, depending on the species, the mammalian embryo grows to the morula stage which consists of about 32 cells and at this stage the first differentiated cells have not yet formed. The formation of the blastocyst-stage preimplantation embryo occurs when the embryo consists of about 50 to 100 cells at about 3-6 days post-fertilization, depending on the species. The blastocyst has the form of a hollow ball with a solid sphere, the inner cell mass, positioned at one end of the inner aspect of the hollow ball. The blastocyst is composed of only three defined cell types. The trophectoderm is the first differentiated tissue of the developing embryo, and it produces the blastocoel cavity by inward transport of the fluid from the surrounding environment. The primitive endoderm is the second differentiated cell type to form and it covers the inner surface of the hollow ball and also forms a cell layer of the ICM [6-9]. The source of ES cell lines is believed to be the totipotent epiblast tissue, i.e. the solid sphere of cells that comprises the inner aspect of the ICM [10]. However, ES cell lines have also been derived from morula stage embryos prior to the first embryonic differentiation events in the mouse [11] and the human [12].

ES cell lines were first isolated from explant cultures of mouse blastocyst-stage embryos or the so-called "egg cylinder" stage that developed after one to a few days in primary culture [13-15]. Then, more recently, ES cell lines were established from in vivo-derived blastocysts of monkeys [16] and the in vitro fertilized (IVF)/in vitro cultured (IVC) blastocysts of humans [17-19]. Attempts to create ES cell lines of the pig, goat, sheep, and horse have most often used in vivo blastocysts acquired from the reproductive track at various stages, i.e., early, where blastocoel cavity formation has just occurred, or late, at the elongated or filamentous stage blastocysts (Table 1). Where efficient and cost effective, as in the bovine, in vitroproduced blastocysts are commonly used as the starting material for attempts at making ES cell lines (Table 1). In vitro-production (IVP) usually involves in vitro maturation, fertilization, and culture of the embryos to the morula or blastocyst stage. Although IVP blastocysts may be altered in terms of cell metabolism, epigenetic status, and constituent cell numbers, it is probable that they will prove competent for the establishment of bovine ES cell lines. This conjecture seems reasonable since human ES cell lines have usually been derived from IVF/IVC embryos (although in vivo matured), and because culture of IVPderived bovine epiblast tissue was shown to display normal differentiation and pluripotency [20]. 
Table 1 In vitro response of porcine epiblast cells to exogenous culture factors

\begin{tabular}{|c|c|}
\hline Cytokine or factor & Response of porcine epiblast cells ${ }^{\mathrm{a}}$ \\
\hline Activin A (10-100 ng/ml) & Differentiation into extraembryonic endoderm and mesodermal cells ${ }^{b}$ \\
\hline Cardiotrophin-1 & No apparent effect $\mathrm{c}^{\mathrm{c}}$ \\
\hline CNTF $(10 \mathrm{ng} / \mathrm{ml})+\mathrm{CNTF}$ sR $(10 \mathrm{ng} / \mathrm{ml})$ & No apparent effect ${ }^{\mathrm{c}}$ \\
\hline EGF, TGF- $\alpha$, betacellulin & No apparent effect ${ }^{\mathrm{c}}$ or differentiation into neurons and glial cells ${ }^{\mathrm{d}}$ \\
\hline FGF2 (1-100 ng/ml) & No apparent effect ${ }^{\mathrm{c}}$ \\
\hline FGF1 $(1-10 \mathrm{ng} / \mathrm{ml})$ & No apparent effect ${ }^{\mathrm{c}}$ \\
\hline FGF4 $(10 \mathrm{ng} / \mathrm{ml})$ & No apparent effect ${ }^{\mathrm{c}}$ \\
\hline FGF7 $(10 \mathrm{ng} / \mathrm{ml})$ & No apparent effect ${ }^{\mathrm{c}}$ \\
\hline Heregulin $1-\beta 1$ & Differentiation into mesodermal cells ${ }^{\mathrm{b}}$ \\
\hline IGF-1 (50 ng/ml) & No apparent effect ${ }^{\mathrm{c}}$ \\
\hline IL-6 (10 ng/ml)+IL-6 sR (10 ng/ml) & No apparent effect ${ }^{\mathrm{c}}$ \\
\hline IL-11 $(10 \mathrm{ng} / \mathrm{ml})$ & No apparent effect ${ }^{\mathrm{c}}$ \\
\hline Indirubin-3'-oxime $(2-20 \mu \mathrm{M})$ & No apparent effect $^{\mathrm{c}}$ \\
\hline mLIF or hLIF $(10-100 \mathrm{ng} / \mathrm{ml})$ & No apparent effect ${ }^{\mathrm{c}}$ \\
\hline FGF2 (1-10 ng/ml+hLIF (10-100 ng/ml) & No apparent effect ${ }^{\mathrm{c}}$ \\
\hline $\mathrm{LiCl}(1-2 \mathrm{mM})$ & Delayed differentiation into neuronal cells ${ }^{\mathrm{d}}$ \\
\hline Nodal (100 ng/ml) & No effect ${ }^{\mathrm{c}}$ or neuronal cells ${ }^{\mathrm{d}}$ \\
\hline Noggin $(50-800 \mathrm{ng} / \mathrm{ml})$ & Differentiation into neuronal cells ${ }^{\mathrm{d}}$ \\
\hline Noggin $(500 \mathrm{ng} / \mathrm{ml})+\mathrm{bFGF}(10 \mathrm{ng} / \mathrm{ml})$ & Delayed differentiation into neuronal cells ${ }^{\mathrm{d}}$ \\
\hline Oncostatin $\mathrm{M}(10 \mathrm{ng} / \mathrm{ml})$ & No apparent effect ${ }^{\mathrm{c}}$ \\
\hline Wnt3a $(50 \mathrm{ng} / \mathrm{ml})$ & No apparent effect ${ }^{\mathrm{c}}$ \\
\hline Porcine TGF $\beta(1-10 \mathrm{ng} / \mathrm{ml})$ & No apparent effect $^{\mathrm{c}}$ \\
\hline TGFB receptor inhibitor (SB 431542) & Differentiation into neuronal cells ${ }^{\mathrm{d}}$ \\
\hline SCF (c-Kit ligand; $10 \mathrm{ng} / \mathrm{ml}$ ) & No apparent effect ${ }^{\mathrm{c}}$ \\
\hline $10 \% v / v$ Knock-out serum replacer (KOSR) or $5 \%$ FBS $/ 5 \%$ KOSR & Cytoplasmic inclusion accumulation and differentiation into neuronal cells $\mathrm{s}^{\mathrm{d}}$ \\
\hline $5 \%$ oxygen atmosphere & Poor survival of epiblast colony \\
\hline
\end{tabular}

${ }^{a}$ STO mouse feeder cells and 10\% Dulbecco's modified eagle's medium (DMEM)/199 medium culture environment [177]

${ }^{\mathrm{b}}$ Yolk-sac endoderm as assessed by morphology and serum-protein production; parietal endoderm as assessed by morphology; fibroblasts, multinucleated skeletal muscle fibers, and macrophages as assessed by morphology

${ }^{\mathrm{c}}$ Spontaneous differentiation of the primary epiblast cultures into multiple cell types representative of neuroectoderm, mesoderm, and definitive endoderm occurs after $48-72 \mathrm{~h}$ of culture; also, differentiation into the extraembryonic tissues, trophectoderm and yolk-sac endoderm possible

${ }^{\mathrm{d}}$ Assessed by cell morphology (presence of dendrite-like and axon-like cell processes) and colony morphology (neural-rosette formation)

Peer-reviewed reports of porcine ES, ES-like, or ICM cell lines have been published by at least four groups and all used in vivo-derived blastocysts as their primary culture material [21-30]. Putative pig ES cell lines were also isolated from IVP pig embryos [31]. Similarly, there are several reports of pig ES-like cell lines that were derived from the early genital ridge tissue of the pig. These concern the isolation and culture of the pluripotent primordial germ cells to establish so-called embryonic germ (EG) cell lines which, in the case of mouse and human EG cell lines, have proven to be or are assumed to be functionally equivalent to ES cell lines [3235]. However, putative EG cell lines of ungulates are not the subject of this review and are only noted for the reader's information. Several bovine ES or ES-like cell lines have been reported and most of these were isolated from IVP early blastocyst stage embryos [1,36-42]. Caprine ES or ES-like cell lines have been reported as well [43]. Also, a goat EG cell line was reported by [44]. Ovine ES or ES-like cell lines have also been reported [22]. Finally, there are two reports of equine ES cell lines being established [45, 46].
All of the above mentioned reports of ES or ES-like cell lines of ungulates are deficient in at least one or several critical characteristics that define true ES cell lines. Many of the "cell lines" have in fact been short lived cultures and no data, such as growth curves, demonstrating the rate of replication of the putative ES or ES-like cell cultures have been given. Instead time in culture or the number of times the culture was "passaged" was generally reported. Neither time in culture or number of passages necessarily indicates that the cells in culture are dividing or growing. Proof of immortality over continuous culture, a key attribute of human and mouse ES cell lines (see below), have therefore been lacking in the reports of ungulate ES-like cell cultures.

The morphology of putative ungulate ESC is often reported as "ES-like" but in most cases the published light micrographs have been of such poor quality or at so low a magnification, that evaluation of this property is difficult or impossible. Morphological comparison to trophectoderm and visceral endoderm cells, which can mimic ESC morphology, have has not been performed even though 
the trophectoderm and visceral endoderm of ungulates is easily cultivated on feeder cells, (see Fig. 1b) and have cell specific gene/protein expression [47-51]. Demonstrations of in vitro pluripotency have often only been described by narrative. In those cases where putative differentiation was evaluated by immunocytochemistry assays, the presented micrographs have been of low quality, low magnification, and lacked adequate immunological controls and cell controls. Proof of ES-like cell differentiation based on reverse transcriptase polymerase chain reaction (RT-PCR) data have also lacked adequate controls or specificity, and have not clearly demonstrated that the sample tested was free of feeder cells. Feeder cells may contain a mixture of cell types or have undefined gene expression profiles [52]. Demonstrations or claims of embryoid body formation by ungulate ES-like cells fail to differentiate these embryoid-like bodies from similar multicellular vesicle-like bodies that are commonly produced by the anchorage-independent growth of ungulate trophectoderm and visceral endoderm cells, or, for that matter, by other polarized, dome-forming epithelial cell lines (see [15, 53] for a clear description of ESC embryoid bodies). Teratoma formation in immunocompromised mice is a common proof of the pluripotency of primate and mouse ES cell lines. This in vivo demonstration of pluripotency has never been reported for any of the putative ungulate ES cell lines. What is commonly reported is the use of the ES-like cell lines to produce chimeric animals by injection of the ESlike cells into blastocyst-stage ungulate embryos or by some related chimera-formation technique. In general, these efforts produce animals displaying minor chimera contribution from the ungulate ES-like cells, and in all cases cell controls were not done, i.e., the injection or combining of somatic cells types, like ungulate trophectoderm cells, to see what level of chimerism they would produce. Also, the possibility of cell fusion between the ES-like cells and the cells of the embryo have not been considered as a possibility or controlled for. Some ungulate ES-like cell lines were reportedly used as nuclear donor cells to create cloned animals by nuclear transfer $[28,41]$. The use of the cells in nuclear cloning in no way proves their ES cell character since numerous types of fully differentiated somatic cell nuclei have proven competent for the creation of cloned animals $[54,55]$. In particular, nuclear cloned animals have also been created from trophectoderm cells [56]. This is significant since trophectoderm cells are a common cell contaminant in attempts to establish ungulate ES cell lines and are easily confused with epiblast cells (see below).

\section{Definition of ES Cell Lines}

ES cell lines are termed continuous cell lines and as such have the property of cell cultures that can be maintained
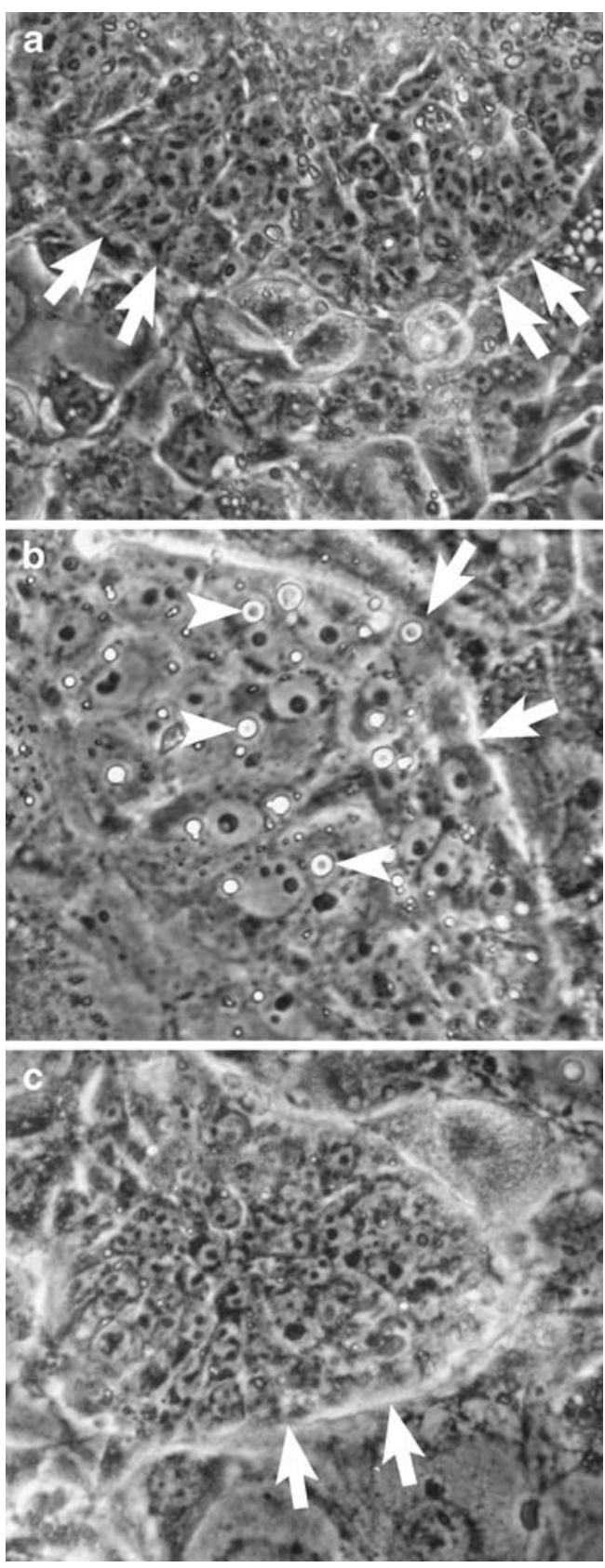

Fig. 1 Colony and cell morphology of a pig epiblast culture in comparison to other "ES-like" cell cultures $(\times 200)$. a Pig epiblastmass $24 \mathrm{~h}$ after attaching and spreading on STO feeder cell layer; arrows indicate epiblast colony boundary with the feeder cells. b Secondary culture of pig trophectoderm cells derived from a 10-day blastocyst's extraembryonic tissue that was obtained by physical dissection of the embryonic disc; note the characteristic lipid droplets in trophectoderm cells (arrowheads). Arrows indicate the trophectoderm colony's boundary with the feeder cells. c Single colony of pig epiblast-derived epithelial cell line (PICM-16) $48 \mathrm{~h}$ after passage. Arrows indicate colony's boundary with the feeder cells. The PICM16 cells will change their appearance dramatically (not shown) after a few days post-passage as they spread and flatten and begin domeformation (fluid transport through and beneath their basal-lateral aspect). This is morphological change associated with maturation of the PICM-16 cell line's phenotype and not differentiation 
indefinitely over passage, or are immortal $[57,58]$. This is in contrast with cell cultures that can be passaged for only defined periods of time and that can be referred to as finite cell lines [59]. The term cell line implies the maintenance of the cell culture's original phenotype over continuous culture or passage, i.e., hundreds of population doublings, and also implies a homogeneity of phenotype within the population of cells. For example, a muscle cell line should contain only myocytes and not myocytes and epithelial cells. For ES cell lines this phenotypic definition is that most of the cells of the cell line are capable of giving rise to, that is, differentiating into, various somatic cell types representative of the three primary embryonic germ layers [13, 14]. Furthermore, they should be able to differentiate into the germ cells, egg and sperm, [2, 60, 61] and even extraembryonic cell types such as trophectoderm and yolk-sac endoderm [17, 62, 63]. Also, by definition ES cell lines must be able to self-renew as stem cells; thereby maintaining their ability to differentiate into all cell types.

The pluripotent phenotype has been demonstrated for mouse ES cell lines by reintroducing the ESC into the early mouse embryo. Through this means, chimeric or entirely EScell-derived offspring have been produced thus proving their pluripotent stem cell quality $[2,64]$. Although, this ultimate proof of pluripotency is not possible with human ES cell lines for ethical reason, their pluripotency has been shown either by in vivo teratoma formation or in vitro differentiation $[4,5,16-18,42]$. Similar in vivo and in vitro proofs of differentiation have been published with murine ES cells (mESC) $[13,14,65]$. Of interest in this regard are the recently established mouse epiblast-derived stem cells lines (EpiSC) [66, 67]. Their epigenetic marks, gene expression profiles, and reliance on activin A/basic fibroblast growth factor (bFGF/FGF2) for pluripotency maintenance indicate a similarity to human embryonic stem cells (hESC), and not mESC. Although EpiSC pluripotency was demonstrated by teratoma formation and in vitro differentiation as it has been for hESC, the EpiSC did not produce viable chimeric mice [68]. Therefore, it is hypothesized that hESC may also have a more restricted pluripotency or, at least, ability to successfully integrate within a developing embryo [68].

These definitive properties should not imply that ES cell lines must remain unchanged over time in continuous culture to be considered authentic ES cell lines. On the contrary, as with all cell lines the population of cells that comprise any ES cell line is subject to internal and external selective pressures. Stochastic events that are operating in each cell as it grows and divides will influence its comparative survival fitness within the population and within the given culture environment. So, by definition, as time in culture progresses, the various properties of the ESC population will change; for example, the fastest growing cells will become an increasing proportion of the population of cells over time. Some stem cell traits are seemingly lost very early in passage; such as the ability to create live born young that are completely ESC-derived [64]. Over further passage, karyotypic abnormalities become more common within the population and cell line competence for germ line chimera contribution can also be lost $[2,15]$. However, lost properties definitive to ESC, can probably be restored in many, if not all, ES cell lines by recognizing that the cell line is a population of individual cells and that each individual cell is phenotypically and genotypically different, albeit by sometimes extremely small measures. Differences between two daughter cells have been described [69]. So, by the agency of single cell cloning from the population of cells and screening the clonal populations for normal karyotypes, it has been possible to maintain the ESC character of ES cell lines over extensive continuous culture [57, 58].

\section{Cell Culture Properties Of ES Cell Lines}

ES cell lines have similar cell culture properties regardless of the species of origin or the tissue of origin, i.e., derivation from morula stage embryos, the ICM of the blastocyst, PGC of the embryonic genital ridge, or the early post-implantation epiblast $[66,67]$. Primary cultures of epiblast cells also share many culture characteristics and cellular features in common with ESC [7, 66, 67, 70, 71]. ESC have a distinct epithelial colony morphology. The cells of murine ES cells typically grow in compact colonial groups, or 'nests' of cells that often have a convex 3-D shape and a distinct, glistening edge that meets with the flatter feeder cells that the ESC are often co-cultured with [15]. The ESC generally grow on top of or in between the feeder cells. Mouse ESC colonies grow quickly to contain hundreds if not thousands of cells per colony, and the colonies will eventually fuse with one another to form monolayers if there are sufficient colonies in close proximity. If left undisturbed, i.e., not routinely passaged every week, murine ESC will begin to spontaneously differentiate at the periphery of the colony with the formation of flatter, larger, and irregularly cuboidal visceral endoderm. Later on, somatic cell types may appear in or around the differentiating colony. Primate ESC colony morphology is different from mESC in that human ESC are generally flatter in appearance and spontaneous differentiation tends to begin in the center of colonies if they are left undisturbed for a week or more without passage [16, 17, 72]. Likewise, spontaneous differentiation in primary cultures of ungulate epiblast cells tends to begin in the center of the colony $[7,70,20]$.

Cell morphology of ESC and primary cultures of epiblast cells are very similar and they are similar across 
species (Figs. 1a and 2a) [7, 15-17, 20, 66, 67, 70, 72]. The cells are generally uniform in size $(10-15 \mu \mathrm{m}$ in diameter) with a round to oval shape. Perhaps their most distinct morphological feature when viewed by phase-contrast microscopy is their large nucleus surrounded by a narrow band of non-granular cytoplasm. Also, most nuclei are observed to contain one or two very large and distinct nucleoli. Transmission electron micrographs of mESC indicate that they usually lack or have minimal mature complex junctions/tight junctions between adjacent cells $[15,73,74]$. Primate ES cells are similar to $\mathrm{mESC}$, but may display some complex epithelial junctions, particularly in the outer cells of multilayered colonies, but they appear to lack well developed junction-associated tonal filaments in any case $[72,75]$. An ultrastructural study of the in vivo pig blastocyst/ICM and of primary cultures of pig epiblast cells showed that in contrast to primate and murine ESC, the pig epiblast cells develop robust complex junctions/tight junctions shortly after blastocyst formation [8]. The cultured pig epiblast cells also have well-developed apical adhesion belt structure with associated actin filament bundles, typical of mature polarized epithelium [8]. Given the above information, it seems probable that ungulate ES cell lines, once established, will be most similar to primate ESC in colony and cell morphology.

\section{Molecular Regulation in ESC}

Rapid spontaneous differentiation and an incomplete knowledge of pluripotency factors continue to hinder the establishment of ES cell lines of domesticated animals. Contemporary studies have implicated the importance of a number of cell surface markers, transcription factors and cytokines (and their signaling pathways) in the maintenance of pluripotency of mESC and of hESC and thus, have also identified potential markers of "stemness" [76-80]. In mice and primates, these factors, designated as stem cell markers, exhibit an expression restricted to the ICM of the early mammalian embryo, or blastocyst [81, 82]. However, in contrast to mouse and human pre-implantation blastocysts, ungulate blastocysts maintain an extended peri-implantation period during which the trophectoderm grows extensively and is remodeled [83-85]. In addition, though less dynamic, advancement of the ICM to the embryonic discstage and the initiation of gastrulation occur concomitantly with these changes in the trophectoderm [86-88]. This divergence in ungulate development requires dramatic changes in gene expression profiles and may include genes whose expression would typically be restricted to the ICM of a mouse or human blastocyst [89]. These phenomena indicate that putative markers must be investigated thoroughly in the quest of identifying a universal panel of ESC
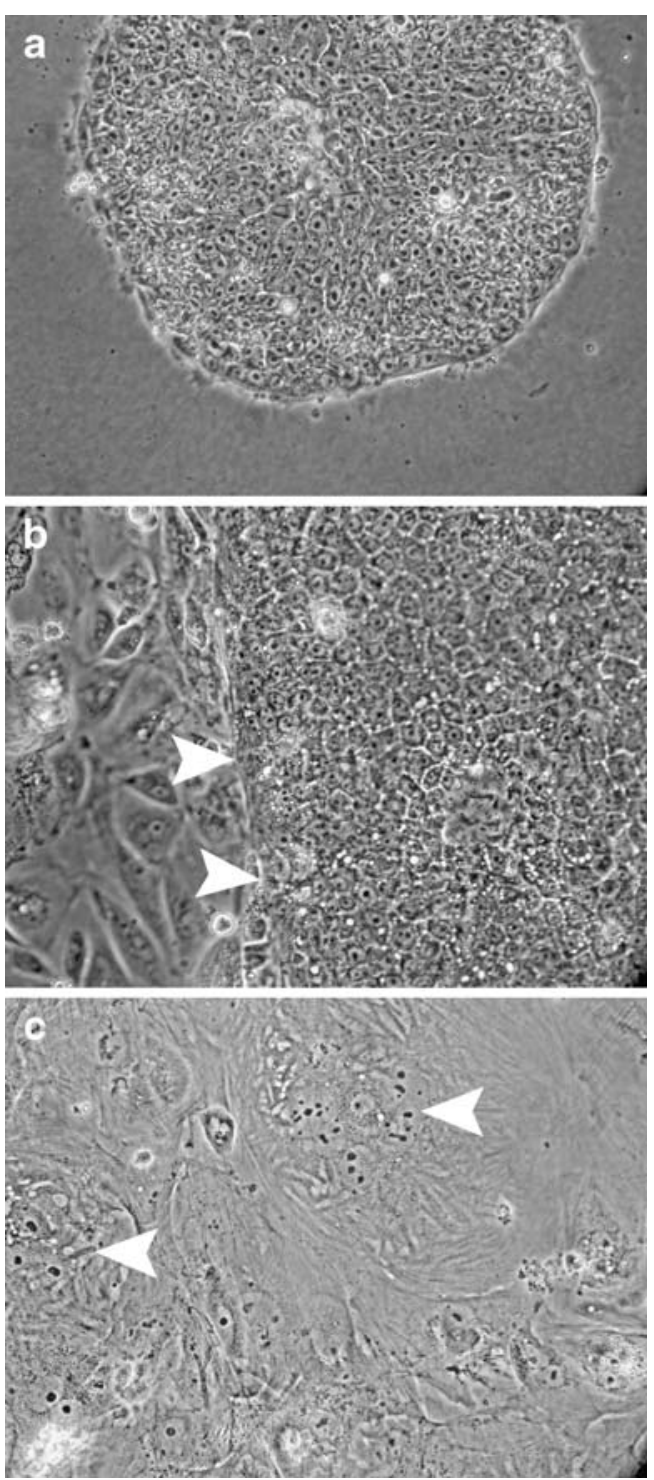

Fig. 2 Primary pig epiblast cell mass cultures plated on polymerized collagen type I thin-layer gel with Matrigel incorporated; $1: 5 \mathrm{v} / \mathrm{v}$ $(\times 200)$. a Epiblast colony after $24 \mathrm{~h}$ in culture in DMEM/Medium 199 (1:1) with $10 \%$ fetal bovine serum (FBS) from Hyclone, Inc., Logan, UT (10\% DMEM/199) supplemented with recombinant heregulin1- $\beta 1$ [(50 ng/ml), R\&D Systems, Inc., Minneapolis, MN]; isolated as previously described $[7,71]$. b Epiblast colony after 12 days in culture under noggin $800 \mathrm{ng} / \mathrm{ml}$ (R\&D Systems)+bFGF $10 \mathrm{ng} / \mathrm{ml}$ (R\&D Systems) $+1 \times$ ITS (Sigma Chemical Co., St. Louis, MO) in $10 \%$ DMEM/199 medium showing differentiation into putative trophectoderm (arrowheads) and yolk-sac endoderm (left). c Twelve-day old epiblast cultured under noggin $800 \mathrm{ng} / \mathrm{ml}+\mathrm{bFGF} 10 \mathrm{ng} / \mathrm{ml}$ (R\&D Systems) in $10 \%$ DMEM/199 medium showing typical senescent morphology of flattened, enlarged cells with prominent stress-fibers; arrowheads denote fragmented nuclei

markers applicable across species. Developing a better understanding of the molecular biology of ESC source tissue, i.e., the cells of the epiblast, and of ES cell lines of different species should greatly improve our ability to distinguish between common or species-specific pluripotency markers 
and ESC culture requirements. A starting point has been the comparative studies between mESC and hESC, and to some degree blastocyst-stage embryos and their ICMs/epiblasts to pinpoint crucial extracellular and intracellular factors/mechanisms that are signatures of pluripotency. Furthermore, the development of sensitive, in-depth genomic technologies has enabled side-by-side comparison of established ES cell lines of human and mouse origin.

\section{Signaling Through Extrinsic Growth Factors}

Efficient in vitro propagation of pluripotent $\mathrm{mESC}$ or $\mathrm{hESC}$ has required co-culture with feeder cells [often mouse embryonic fibroblasts (MEF)] or the addition of exogenous matrices and defined cytokines or growth factors [17, 90, 91]. This has not only highlighted the importance of paracrine factors identified from cells within ESC colonies, or from trophectoderm and endometrial tissue, but it has also enabled the discovery of other factors and cellular signaling cascades important for the maintenance of ESC pluripotency and replication. So far, autocrine and/or paracrine signaling through leukemia inhibitory factor (LIF), fibroblast growth factors, insulin-like growth factor1 (IGF1), transforming growth factor-beta (TGFB) family members, and WNT pathway members exhibit key roles in the maintenance of pluripotency and replication of ESC.

LIF/interleukin-6 signaling The LIF ligand, a member of the interleukin-6 family, initiates an intracellular signaling cascade by binding the heterodimerized leukemia inhibitory factor receptor (LIFR): gp130 [a.k.a. interleukin-6 signal transducer (ILST6)] receptor complex or homodimerized gp130 [92]. Either trimeric ligand:receptor complex can induce the intracellular stimulation of the Janus kinase nonreceptor tyrosine kinase (JAK) and amplify signal transduction through the activation of downstream targets [79, 93, 94]. One factor in particular, signal transducers and activators of transcription 3 (STAT3), stimulates c-myc transcription factor (MYC), suppressor of cytokine signaling (SOCS) gene, a STAT antagonist, and zinc finger protein-57 (ZFP57) [80, 95]. While ZFP57 bioactivity is dispensable for maintenance of mESC characteristics, MYC is important for the self-renewal of mESC through the inhibition of differentiation [80, 95]. The Kruppel-like family member 4 (KLF4) is another factor that responds to LIF signaling and has a role in self-renewal of mESC, although, its regulatory mechanism has not yet been clearly defined [96, 97].

The in vivo expression profile of LIFR in the mouse blastocyst is consistent with that of a pluripotency factor; LIFR and gp130 are expressed solely in the pluripotent cells of the ICM whereas LIF is expressed in the surrounding trophectoderm [82]. The importance of LIF signaling in the maintenance of pluripotency is corroborated by the requirement for LIF in feeder-free mESC culture [78, 90, 93, 98] and by functional studies that interrogated LIF signaling at specific signal transduction levels, i.e., receptor, STAT3, and c-myc activation [77, 80, 99]. However, development of LIF, LIFR, or gp130 null embryos beyond gastrulation indicates that LIF signaling is dispensable for in vivo development of the ICM in mouse [100, 101]. More to the point, LIF and LIFR as universal markers of "stemness" in species other than the mouse has not been demonstrated. In the human blastocyst, LIFR transcript expression is ubiquitous and ILST6 alone is restricted to the ICM [102]. However, LIF receptor expression and its role in primate ESC are not clear. Analyses of primate ES cell lines have shown a functional LIF/JAK/STAT3 pathway in both human and monkey ESC [103-105]. In contrast, other studies have indicated that the LIF heterodimeric receptor components and downstream factors are either not detected or present at trace levels [106, 107]. In keeping with this observation, mRNA for SOCS, an antagonist of LIF signaling, is up-regulated. Similarly, LIFR transcripts have been detected in undifferentiated porcine ICMs and in $24 \mathrm{~h}$ cultured, undifferentiated epiblast tissue, but not consistently [71], whereas LIFR expression has not been found in porcine ES-like cells [108]. Artifactual LIFR expression patterns may also exist as a consequence of the influence of components in the culture system [109, 110]. In specific functional analysis, however, LIF has shown no efficacy in maintaining the pluripotent state of ESC in any species but the mouse $[17,105,108]$. These observations indicate that LIF has a role in development, but not as an essential in vivo "stemness" factor. Furthermore, the differences in LIFR expression patterns also highlight potential speciesspecific differences and possible perturbations of the normal development process induced by in vitro culture.

TGFB superfamily signaling The TGFB family is a superfamily of about 40 different pleiotropic growth factors with biological activities vital for conceptus development. Family members including TGF-beta-1 (TGFB1), bone morphogenetic proteins (BMPs), growth/differentiation factors, noggin (NOG), activin A [a.k.a. inhibin beta A], and nodal homolog (NODAL) have all been implicated in the control of stemness in ESC [111]. In the classical pathway, related but distinct heterodimeric receptors for TGFB1/activin A and BMPs transduce an intracellular signal to specific subsets of mothers against decapentaplegic Drosophila homologs (SMAD). The SMAD proteins regulate the transcription of downstream target genes such as NODAL and induction of inhibitor of DNA binding proteins (ID) [111, 112].

Under in vitro culture conditions, NODAL, TGFB1, and activin A promote pluripotency and self-renewal of hESC 
[111]. Activin A has a dual role. It antagonizes the BMP4 pathway that would otherwise stimulate hESC differentiation and also mediates NODAL expression, which is apparently important for the maintenance of pluripotency in hESC [111, 113-115]. Additionally, another mechanism to inhibit BMP4-directed differentiation is mediated by the BMP4 antagonist, NOG, in concert with basic fibroblast growth factor [116]. In contrast to hESC, mESC require BMP4 for their maintenance of pluripotency. In vitro self-renewal of mESC under serum-free and feeder-free conditions is retained only through exogenous BMP4 supplementation to initiate SMAD/ID signaling and in conjunction with activation of the LIF/STAT3 pathway [78]. Signaling through the TGFB family appears to be important in $\mathrm{mESC}$ and $\mathrm{hESC}$, but whether their divergent pathways have common steps remains unclear. Much less is known about the importance of TGFB factors in ungulate ES cells. However, our recent study demonstrated that teratocarcinoma-derived growth factor 1 mRNA, but not BMP4, is present in undifferentiated epiblast cells through the first $48 \mathrm{~h}$ of culture before its expression wanes with the onset of morphologically apparent differentiation [71]. Also, neither activin A nor NOG abrogates porcine and equine epiblast differentiation indicating stimulation of activin signaling or inhibition of BMP4 alone is not effective in ungulate ESC pluripotency maintenance (Table 1, unpublished observations).

FGF and cooperative signaling with insulin-like growth factor-1 To date, about 22 different FGF proteins have been identified that elicit an intracellular response through four known FGF receptors (FGFR1, FGFR2, FGFR3 and FGFR4). FGF2 has been identified as a growth factor produced by MEF feeder cells and is important for the selfrenewal of hESC, particularly, under feeder-free conditions $[58,117]$. In depth genomic studies have shown the presence of FGF2, FGFR1, FGFR3 and FGFR4 in hESC, a stark contrast to mESC where only FGF4 and trace FGFR1 are detected [107]. Although the mechanism by which FGF2 exerts its effect on hESC is unclear, a recent study by Bendall et al. 2007 [118] provided a potential explanation. Within the heterogeneous population of hESC, it was determined that "true" hESC, i.e., those expressing the pluripotent marker OCT3/4 (a.k.a. POU5F1), possessed IGF1 receptors (IGF1R) but did not possess receptors for FGF2 (FGFR1). Instead, FGFR1 was expressed in a subpopulation of hESC-derived fibroblast-like (hdF) cells coexisting with the true hESC. In response to FGF2, the $\mathrm{FGFR}^{+}{ }^{+}$hdF cells released IGF2 which bound IGF1R on the hESC surface to promote the true hESC's pluripotency and self-renewal. Medium supplementation with IGF2 alone mimicked the phenomenon. This suggests hESC reside in a microenvironmental niche where FGF2, though important, acts indirectly to stimulate the secretion of a secondary effector molecule, in this case IGF2. However, the importance of FGF proteins or the existence of similar functional niches in species other than mouse and human remains to be described.

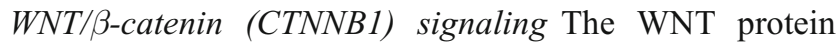
family consists of 19 known members that are involved in embryonic development processes including cell fate [119, 120]. Intracellular signaling by WNT proteins is initiated through their association with a Frizzled protein receptor (Fz) and low density lipoprotein (LRP5 and LRP6) complex. Intracellular modulation of downstream intermediate proteins, such as the inactivation of glycogen synthase kinase 3- $\beta$ (GSK3B), initiates the stabilization and accumulation of catenin beta 1 (CTNNB1). In turn, CTNNB1 translocates to the nucleus where it associates with T-cell factor/lymphoid enhancer factor family transcription members to regulate the transcription of WNT responsive genes like NANOG and MYC [121, 122]. Although other membrane proteins exist that can mediate the WNT signal, the classical and prominent pathway involved in the determination of cell fate, occurs through the Fz/LRP receptor complex [119, 120].

The importance of the WNT signaling pathway in maintaining cells in a less differentiated state has been implicated in several types of stem cells including ES cells $[120,123]$. Several studies have indicated that CTNNB1 is vital for the pluripotency of mESC or hESC and that the WNT pathway is functional in ES cell lines [107, 124, 125]. Additionally, under feeder-free conditions mESC and hESC self-renewal and the expression of pluripotency factors [OCT3/4, NANOG and ZFP42 (a.k.a. Rex-1)] require the inhibition of GSK3B and up-regulation of CTNNB1 [124]. Yet even though WNT signaling is likely important, alone, it is not sufficient to maintain hESC renewal [126] and may not be functional in all ES cell lines [107].

\section{Role of Intrinsic Factors}

The evaluation of ESC has identified a diverse number of transcription factors whose expression correlates with stemness and thus have been designated pluripotency markers. Common to the pluripotent cells of the mouse and human ICM are the expression of the enzyme alkaline phosphatase and the transcription factors, OCT3/4, NANOG, SOX2 and ZFP42 [127-130]. At one time, OCT3/4 was considered to be the master-regulator of pluripotency in $\mathrm{mESC}$, but the inability of OCT3/4 to maintain stemness in mESC independent of the LIF pathway, indicated pluripotency control is not monogenic and highlights the importance of other crucial factors [62]. A core group of pluripotency factors, OCT3/4, SOX2 and 
NANOG, have been identified through expression and promoter studies [127-130]. In the mESC, OCT3/4 and SOX2 act synergistically to regulate NANOG as well as their own expression [127]. Similarly, in hESC, OCT3/4 promotes the expression of multiple factors belonging to key signaling cascades including FGF, TGFB, WNT, and extracellular matrices, while suppressing the expression of lineage-specific factors [130]. A recent study suggested that the T-cell lymphoma breakpoint 1 (TCL1), T-box 3 protein (TBX3, a transcription factor) and estrogen-related receptor-beta (ESRRB, a nuclear receptor) should be added to this select group of pluripotency factors [131]. Utilizing RNA interference, a cooperative scheme between the six components (i.e. OCT3/4, SOX2, NANOG, TCL1, TBX3 and ESRRB) was proposed that inhibits differentiation of the ESC to the three primordial germ layers [131].

However, the mere presence or absence of a putative pluripotency marker is not the sole determinant; tight transcriptional control to maintain a critical expression level of a pluripotency factor is a requirement for the continuation of ESC pluripotency. For example, functional studies demonstrate that OCT3/4 mRNA over expression and OCT3/4 transcriptional suppression results in mESC differentiation to endoderm/mesoderm and trophectoderm, respectively [62]. Furthermore, a variation in the expression pattern across the ICM, endoderm (hypoblast), and trophectoderm between multiple species, including ungulates, exists. A couple of examples are OCT3/4 and NANOG. The restricted ICM expression of OCT3/4 in mouse is absent in human, cow, pig or goat blastocysts where OCT3/ 4 is present within ICM and trophectoderm [89]. In swine, analyses of the expression of NANOG, OCT3/4, ZFP42, SOX2 within epiblasts, endoderm, epiblast-derived differentiated cells and adult tissues demonstrated NANOG was ubiquitous whereas OCT3/4 and ZPF42 expression was restricted almost solely to the undifferentiated epiblast [71]. These types of observations highlight the need to carefully screen an array of putative pluripotency candidates and perhaps define the critical expression level relevant to each species.

\section{Epigenetic Regulation of Chromatin}

The quest for common ESC signatures and the lack of consensus between data sets, i.e., with respect to signaling cascades or pluripotent marker expression, across cell lines or species, has led to the characterization of the more essential genetic core, chromatin. The maintenance of genome plasticity and control of chromatin dynamics is essential for retaining cell characteristics, including those of the ESC. Genetic information important for the initiation, preservation, and propagation of the diverse gene expression profile of each cell is stored and organized within the chromatin. Furthermore epigenetic alterations, i.e., heritable non-Mendelian modifications of chromatin that do not affect the primary structure of the DNA, enable gene expression patterns that direct developmental programs and concomitantly maintain the appropriate fate of cells. Epigenetic regulation of chromatin occurs through alterations in chromatin associated proteins or the direct modification of DNA, and, thereby, change the chromatin structure that ultimately governs the transcriptome profile and functional status of a cell. Nuclear cloning provides evidence that the cytoplasmic content of ESC contains sufficient regulatory information to reprogram somatic cell chromatin to a totipotent embryonic-like state [132].

Loss of pluripotency by the ESC is initiated by the reorganization of chromatin and the induction of gene expression that directs a lineage-specific differentiation and cell fate [133-136]. Epigenetic phenomena are often triggered by changes in environmental factors; in the case of ESC, removal from its normal development niche to in vitro culture. In general, the chromatin of the ESC is maintained in a euchromatin permissive transcriptional state. However, with the onset of differentiation, there is a transition to a more heterochromatin non-permissive transcriptional state and a decrease in genome plasticity. The euchromatin state of the ESC genome requires precise transcriptional control of factors that promote pluripotency and repress differentiation. The eukaryotic genome is packaged and regulated by distinct proteins that modulate not only chromatin's structure and stability but also its association with transcriptional machinery; these include proteins that modify structural proteins post-translationally and genomic DNA [134]. Thus, the overall chromatin state may be a good indicator to evaluate the cell's propensity to remain pluripotent.

Members of the histone protein family modify chromatin structure through their role as a core component of the chromatin nucleosome (histones: H2A, H2B, H3 and H4) or nucleosome linker (histone: H1). Compared to somatic cells, histones are more loosely associated with chromatin in ESC to allow the reorganization/opening of chromatin [134]. In addition, pro- or anti-transcriptional activities of $\mathrm{H} 3$ are regulated by post-translational modifications that enable H3/DNA interaction with transcriptional regulatory proteins [137, 138]. Among these modifications, histone trimethylation in concert with DNA methylation is thought to define epigenetic programs [139].

Central to the regulation of histone methylation and chromatin transcriptional activity are members of the polycomb group (PcG) and trithorax group (txrG) protein families. The PcG and txrG families consist of several classes of proteins, most conserved from drosophila to human, that exhibit repressive or activating transcriptional properties important for ESC identity, cell proliferation, 
genomic imprinting [138, 140, 141]. Regulatory PcG response elements (PRE) and txrG response elements (TRE) within chromatin recruit the $\mathrm{PcG}$ and $\operatorname{txrG}$ factors [138]. Though the mechanism(s) of action for PcG and txrG proteins is not elucidated fully, it is known they form multimeric complexes with specialized functionality, including histone-specific methyltransferase activity [142, 143]. The polycomb repressive complex 2 (PRC2) catalyzes trimethylation of $\mathrm{H} 3$ at lysine 27 (H3K27me3) [142], whereas several distinct txrG multimeric complexes catalyze trimethylation of $\mathrm{H} 3$ at lysine 4 (H3K4me3) [143]. In the mammalian genome, H3K27me3 monovalently marked promoters, i.e. promoters that contain only $\mathrm{H} 3 \mathrm{~K} 27 \mathrm{me} 3$, are associated with transcriptionally silenced genes [137, 144] whereas the H3K4me3 monovalent marked promoters are primarily linked with actively transcribed genes [145]. Functional studies with hESC indicate PcG complexes have a role in cell fate determination [146]. The importance of the PRC2 complex is further substantiated by the inability of mESC to be established from murine blastocysts with a disrupted PRC2 complex and the preferential activation of PRC2 target genes during ESC differentiation $[141,147]$. This suggests that chromatin marks regulate gene silencing vital for the undifferentiated state of mESC.

In addition to the modification by histones, the $5^{\prime}$ regulatory regions of the chromatin are altered by the methylation of unique cytosine-phosphate-guanine $(\mathrm{CpG})$ dinucleotides domains within the DNA. Methylation of the clustered $\mathrm{CpG}$ dinucleotides, or $\mathrm{CpG}$ islands, is catalyzed by DNA methyltransferase and results in the addition of a methyl group to the cytosine of the $\mathrm{CpG}$ dinucleotide. These methyl groups within the $\mathrm{CpG}$ islands serve as a transcription silencing cue by their recruitment of methyl binding transcription repressor proteins [148]. Consistent with the thought that ESC are in a pro-transcriptional state, restriction analysis-based methylation profiling indicates the genome of mESC and hESC are hypomethylated in comparison to differentiated somatic cells $[149,150]$.

A recent study of chromatin status over 17,000 promoters highlights the interplay between histone and DNA methylation in ESC [136]. Typically $\mathrm{CpG}$-rich promoters are associated with ubiquitous housekeeping genes or genes involved in complex developmental processes. In contrast, CpG-poor regulatory regions are often found in tissuespecific genes. In the $\mathrm{mESC}, \mathrm{CpG}$-rich promoters are significantly enriched for $\mathrm{H} 3 \mathrm{~K} 4 \mathrm{me} 3$, however, this does not mean they are all active. Approximately $22 \%$ of the CpGrich promoters contain bivalent marks, i.e., they contain PREs and TREs, and thus, recruit PcG and txrG complexes concomitantly or exhibit temporal regulation of the marks $[136,151]$. The anti-transcriptional influence of H3K27me3/ $\mathrm{PcG}$ complexes supersedes that of $\mathrm{H} 3 \mathrm{~K} 4 \mathrm{me} 3$ in bivalent marked promoters to preferentially silence transcription $[133$,
151]. Interestingly, bivalent marks are found in the promoters of many genes encoding key transcription factors, morphogens, or cell-surface factors that direct highly intricate developmental processes, such as embryonic development.

Comparisons of the epigenetic profile of ESC, lineagespecific stem cells, and differentiated somatic cell types indicate that the ESC possess a distinct profile $[133,151]$. Aside from the increased euchromatin and hypomethylated $\mathrm{CpG}$ islands in ESC, regions of the chromatin that contain early embryonic development and neural-specific genes replicate earlier in ESC than in differentiated cells. In addition, the level of $\mathrm{H} 3 \mathrm{~K} 4 \mathrm{me} 3$ associated with regulatory regions is often greater in the ESC [136]. Furthermore, the monovalent state may be reversed with differentiation as is the case with SOX2; in ESC the SOX2 promoter is marked by $\mathrm{H} 3 \mathrm{~K} 4 \mathrm{me} 3$ alone, whereas in MEF, H3K27me3 is the sole mark [136]. Interestingly, bivalent marking seems to permit lineage-specific genes to exist in a semi-permissive transcriptional state in ESC and serve as a prompt for ensuing activation upon differentiation $[133,136]$. With the initiation of ESC differentiation, many of the bivalent marks in CpG-rich elements are modified to a monovalent status and some promoters lose both marks, and, as a consequence, exhibit very low expression [136]. Thus, bivalent marking of chromatin, in particular, appears to be a critical level of regulation in the divergence of pluripotency to lineage commitment and is worthy of further characterization to pinpoint common stemness chromatin signatures across species, including ungulates.

\section{Advances in the Control of Pluripotency}

Though not complete, integration of information gained through characterization of mouse and human ESC pluripotency has enabled functional genomic studies to pinpoint key signatures and regulatory mechanisms. This helped lead to the first successful reprogramming of a somatic cell (MEF) to an ESC-like state utilizing retroviral constructs to express factors from three distinct functional groups, i.e., ESC transcription factors, growth or tumor-related genes, and ESC-specific factors with undefined function [152]. By testing the expression of different combinations of proteins, two transcription factors, OCT3/4 and SOX2, and two tumor-related factors, MYC and KLF4, were found to be crucial for generating so-called induced pluripotent stem cells (iPSC) from the mouse fibroblasts. The dedifferentiation phenomenon induced by this panel of factors is reproducible and conserved between human and mouse cells [153]. Functional in vivo studies of iPSC demonstrated that they have achieved a pluripotent state. The iPSC were able to differentiate into cells representative of all three primordial germ layers and were able to generate germline chimeric offspring [152, 154, 155]. Recent studies 
also show that exogenous MYC is dispensable for the induction of iPSC in mouse and human fibroblasts, however, endogenous expression of MYC indicates that it is still an important factor $[155,156]$. This advance of potentially profound consequences leaves many unanswered questions, however. Only a small portion $(0.1 \%)$ of the somatic cells is induced into iPSC even though a much greater portion of the cells are successfully transduced with apparently functional copies of the retroviral gene constructs. This would suggest that some cells are incapable of being reprogrammed, at least with this particular set of pluripotency-related genes. Furthermore, the requirement of different culture conditions for the establishment of mouse and human iPSC and their distinctive phenotypes indicate that additional undefined, species-specific signaling pathways are effected by essential, extrinsic components of the medium [154].

Reprogramming of either mouse or human somatic cells exhibits unique features. Expression of the exogenous genes from the retroviral constructs is transient but the ESC-like phenotype and up-regulated expression of pluripotency factors persists, which suggests chromatin has been restructured and its signatures reprogrammed [152, 153]. Though the exact mechanism by which reprogramming occurs is not known, MYC and KLF4 proteins are thought to be key players in the restructuring of chromatin via histone modification; this would enable OCT3/4 and SOX2 proteins access to the promoter regions of genes that drive pluripotency and self-renewal of ESC during the induction of pluripotency [152]. Analysis of various levels of the transcriptional mechanism in iPSC indicate the chromatin signatures, i.e., DNA demethylation and chromatin trimethylation patterns of promoters, for OCT3/4, SOX2, and NANOG were more similar to an ESC than the parental MEF cell $[135,152,154]$. This observation is in keeping with the up-regulation of endogenous OCT3/4, SOX2, and NANOG, and is most likely important for the longterm maintenance of the iPSC in the ESC state [152, 154, 156]. Defining the core circuitry that induces dedifferentiation of a somatic cell to an ESC state has significant application for devising ESC-based interventions for human therapeutics. If relevant to other animals, this knowledge could help in the establishment of ES cell lines of ungulates.

\section{Approaches and Challenges in the Establishment of Ungulate ES Cell Lines}

The establishment of ungulate ES cell lines, either from in vivo or IVP blastocysts carries many known and unknown challenges. Approaches to the problem may involve innovative genetic manipulation techniques such as targeted cell ablation [157], ectopic expression of pluripotency factors (see above), or gene expression knock-down. Otherwise, more empirical or observation-based experimental approaches such as traditional cell culture manipulations may still provide a solution to the problem. The key to ungulate ES cell line establishment, or at least an appreciation of the problem's possible complexity, should come from comparative genomic and transcriptomic studies being done with mESC, hESC, EpiSC, EGC, spermatogonial stem cells, somatic stem cells, and the analysis of ICM and epiblast tissues [71, 76, 82, 158, 159]. The knowledge gained from these studies will hopefully highlight specific genetic factors or signal transduction pathways that will enable the design of genetic interventions or cell culture environments that will yield stable, i.e., self-renewing, continuous cultures of ungulate ESC.

An initial problem in the isolation and culture of ungulate ESC is in recognizing contaminating cell types in the primary culture of the blastocyst or ICM that may be confused with epiblast cells. Of the three cell types present in the preimplantation mammalian blastocyst, trophectoderm, primitive endoderm and epiblast, it is the epiblast cells that are the source of ES cell lines [10]. When the entire blastocyst is used to initiate a primary culture, trophectoderm, endoderm, and epiblast cells may all survive and grow in the culture. When the trophectoderm cells are lysed by immunodissection (treatment with antibodies and complement) to isolate the ICM, the visceral endoderm survives along with the epiblast tissue (Fig. 3) [7, 51, 160] and, particularly with sheep and bovine blastocysts, trophectoderm cells can often survive the procedure ([20]; unpublished observations). Similarly, physical dissection methods for isolating the ICM should be assumed to always leave viable trophectoderm cells attached to the ICM. So, as with mouse and human primary blastocyst or ICM cell cultures, trophectoderm and endoderm cells may be mistaken for ESC and are in one sense "weeds" in the primary culture [15, $7,70]$. This is particularly true with ungulate cells since their trophectoderm and visceral endoderm are very resilient epithelial cells that grow rapidly in feeder-cell co-cultures [7, 20, 47-51]. Although the cell morphology of ungulate trophectoderm and endoderm is distinctly different from that of primary ungulate epiblast cells (Figs. 1 and 2), and from each other, to the unpracticed eye they may appear indistinguishable. Therefore, as an essential control, it is important that putative ESC of ungulates be tested for markers of trophectoderm or visceral endoderm cells. For example, a definitive marker of bovine, caprine, and ovine trophectoderm is the expression of interferon-tau [48-50]. For visceral endoderm, a specific marker (with the exception of hepatocytes) is the expression of serum proteins such as alpha-fetoprotein and transferrin (Fig. 4) [48, 51, 160]. Also, 

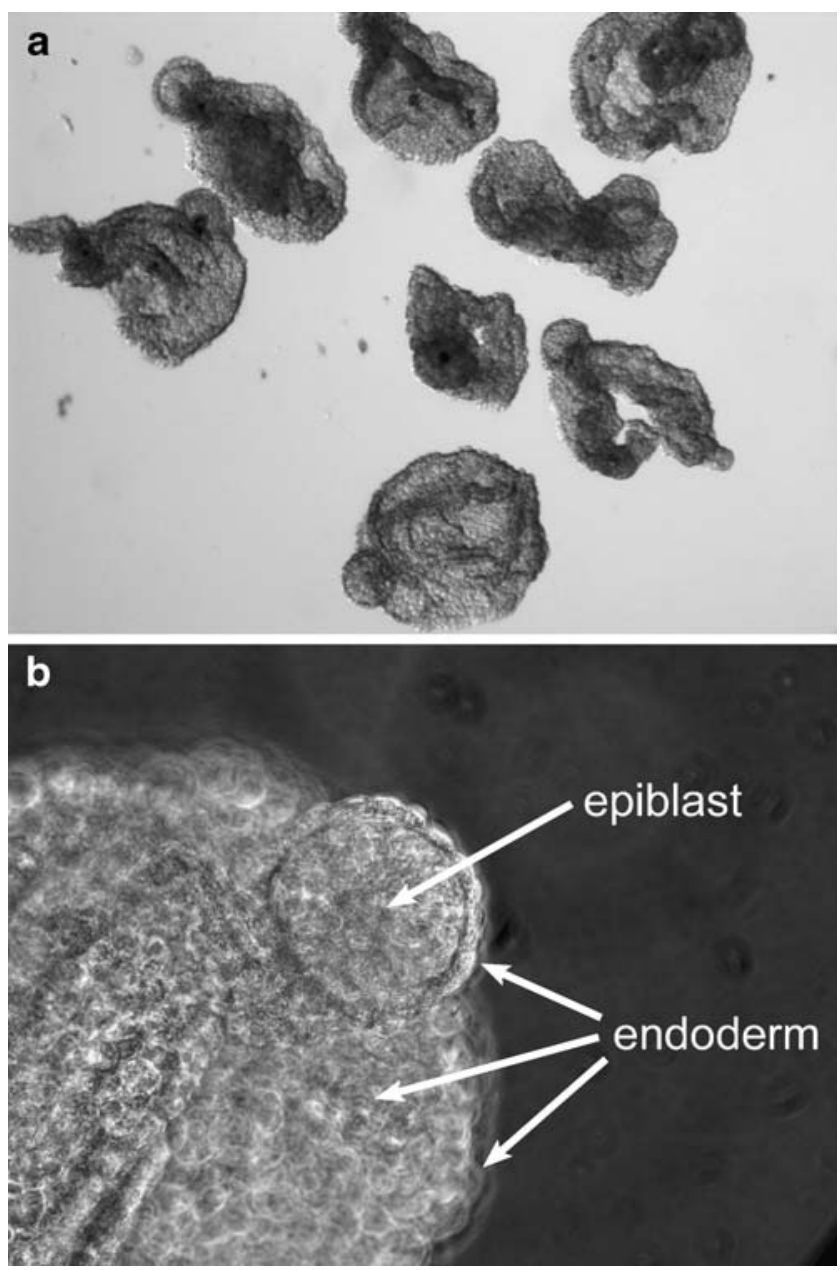

Fig. 3 Isolation of inner cell masses by immunodissection from 10day porcine embryos (blastocysts). a Low power photomicrograph of several freshly isolated porcine ICMs $(\sim \times 40)$. Note the large amount of attendant endoderm cells (monolayer) attached to the epiblast mass at one end as indicated in $\mathbf{b}(\times 200)$

it is important to appreciate the fact that these two cell types, like other polarized or "dome-forming" epithelial cells, will make "embryoid-like" bodies if grown without attachment to a solid cell culture substrate. These and other properties of ungulate trophectoderm and endoderm such as the expression of molecular markers should be carefully evaluated. For example, there are reports of OCT3/4 expression in bovine trophectoderm and probably endoderm $[9,161,162]$. In our laboratory, OCT3/4 expression has been detected in porcine endoderm cell lines by RT-PCR and by immunocytochemistry in the trophectoderm cells of the 11-day porcine ovoid blastocyst [89]. Investigators attempting to derive ES cell lines of ungulates should, therefore, be thoroughly familiar with the in vitro morphology and gene expression of these extraembryonic tissues and should provide proof that the cells they are claiming to be ESC are in fact not trophectoderm or endoderm.
Other contaminating epithelial cells that might be confused with ESC can also occur. The spontaneous differentiation of the primary epiblast cells to epithelial cell types is rapid and common (Fig. 5) [7, 20]. These differentiation events may go unnoticed by the inexperienced investigator because the epiblast cells can be underneath the primary trophectoderm or endoderm outgrowths where they are obscured from view or go unrecognized as epiblast cells. Many epithelial cells grown on fibroblast feeder-cell monolayers can look "ES-like", especially shortly after passage, e.g., fetal kidney epithelial cells that are often confused with primordial germ cells for
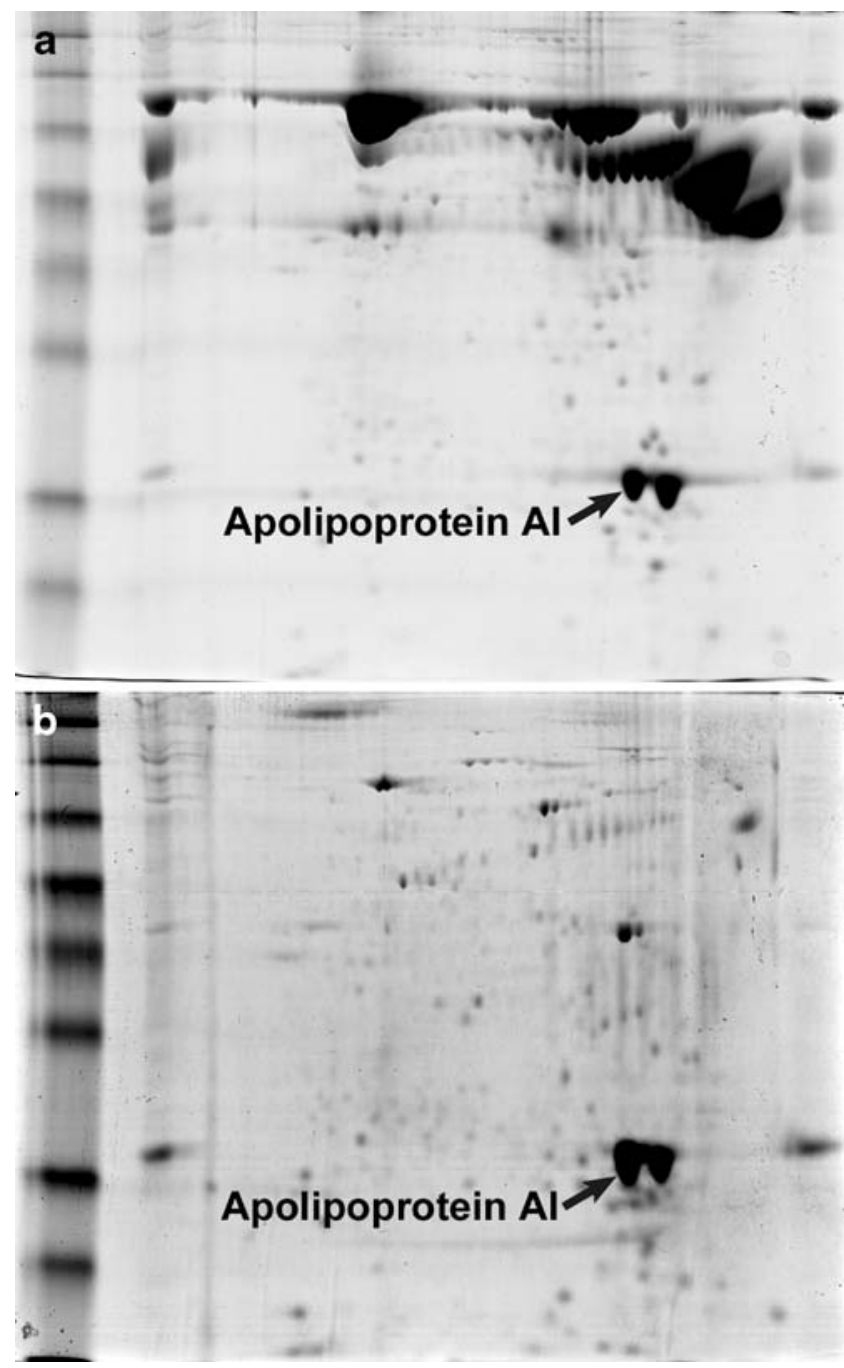

Fig. 4 Example of the effect of different feeders on protein expression. a 2-D gel separation of serum-free medium conditioned for $72 \mathrm{~h}$ by pig endoderm cells (PE-7 cell line) grown on STO feeder cells. Note the expression of numerous serum-proteins that are indicative of yolk-sac endoderm cells. b A 2-D gel of conditioned medium from a second culture of PE-7 cells grown in parallel but with feeder cells of primary CF-1 mouse embryonic mouse fibroblasts. Note the almost total lack of expression of all serum-proteins accept for apolipoprotein A1 in the culture 


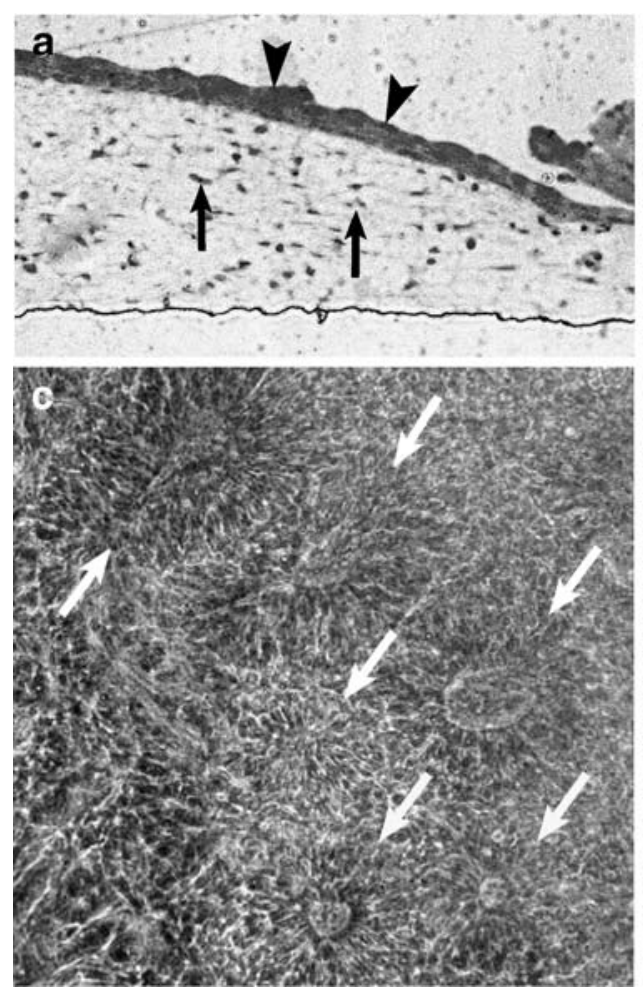

Fig. 5 Examples of spontaneous differentiation of primary pig epiblast cultures grown on STO feeder cells. $(\times 200)$. a Light micrograph of a TEM thick-section of a 6-week old pig epiblast culture showing typical spontaneous differentiation consisting of an epithelial layer (arrowheads) over top of mesodermal cells (arrows). b Example of a with a yolk-sac endoderm epithelial differentiation and outgrowth (black arrowhead indicate the endoderm/feeder cell boundary) with macrophages (often in small clumps; arrows) crawling out from beneath the endoderm monolayer. Epiblast was cultured in 5\% Knock-out Serum Replacer (Invitrogen/Gibco, Gaithersburg, MD) $+5 \%$ fetal bovine

this reason and because kidney epithelial cells express alkaline phosphatase (AP) at high levels [163; unpublished observations]. This ES-like morphology is more pronounced if the feeder cells are prepared at a relatively high density. Figure 1c shows a pig epiblast-derived epithelial cell line that exhibits an ES-like morphology shortly after passage and in some cases these epithelial cells may be AP positive $[7,20,70]$.

Finally, the feeder-cells themselves may be a source of confusion in the identification and proof of ungulate ES cell lines. STO feeder cells, for example, are very pleomorphic and may take on the appearance of various cell types. Most notably, it is common for STO feeder cells to adopt the morphology of oligodendrocytes, astrocytes, or neurons, particularly if they are exposed to various members of the fibroblast growth factor family of growth factors (Fig. 6). The use of rodent or ungulate primary fetal fibroblasts as feeder cells necessarily introduces many different types of cells into an ESC-derivation culture system. For example, macrophages can be as much as $50 \%$ of the "fibroblast"
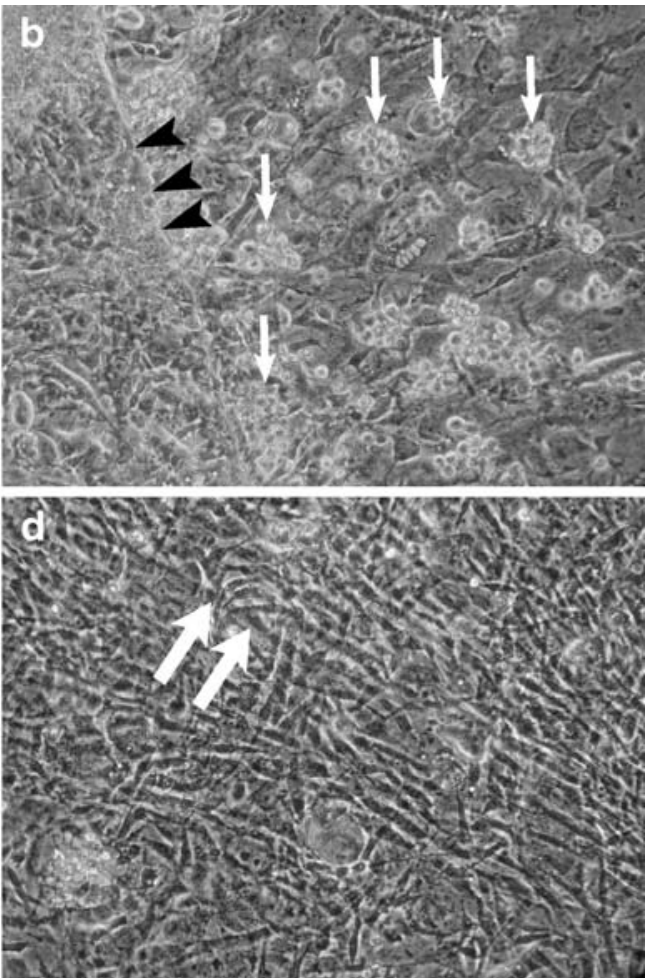

serum (FBS; Hyclone, Inc., Logan, UT) supplemented with activin A $50 \mathrm{ng} / \mathrm{ml}+$ heregulin $1-\beta 1100 \mathrm{ng} / \mathrm{ml}$ (R\&D Systems, Inc., Minneapolis, MN). c Epiblast differentiation into neuroectoderm (arrows indicate neural rosette formations); cultured in DMEM/Medium 199 (1:1) with $10 \%$ FBS (10\% DMEM/199) supplemented with recombinant noggin [R\&D Systems, $(10 \mathrm{ng} / \mathrm{ml})]$. d Multi-nucleated skeletal muscle fibers (arrows) forming from myocytes that migrated out from underneath a yolk-sac endoderm monolayer; epiblast was cultured 10\% DMEM/199 with activin A $10 \mathrm{ng} / \mathrm{ml}($ R\&D Systems $)+1 \times$ ITS (Sigma Chemical Co., St. Louis, MO)

population in the early passage mouse fibroblast cultures that are routinely used for preparing feeder cells [52]. It might also be that neurons, myocytes, endothelial cells, and somatic stem cell, such as hematopoietic stem cells, are present among the fibroblasts that comprise a primary or early secondary culture used for making feeder cells. While these cells are usually rendered non-dividing by treatment with mitomycin $\mathrm{C}$ or gamma radiation, the very real possibility of their presence must be considered in the interpretation of the very sensitive RT-PCR assays that are so commonly performed as proof of pluripotency.

Another challenge for the establishment of ungulate ES cells is the ability to effectively dissociate epiblast cells from one another. Typically cells are separated from one another by treatment with enzymes (trypsin, collagenase, pronase) or in combination with chemical agents such as ethylenediaminetetraacetic acid (EDTA), ethylene glycolbis( $\beta$-aminoethyl ether)- $\mathrm{N}, \mathrm{N}, \mathrm{N}=, \mathrm{N}=$-tetraacetic acid, citrate, or $\mathrm{Ca}^{++} / \mathrm{Mg}^{++}$-free phosphate buffered saline (PBS). By these treatments a suspension of individual cells is 


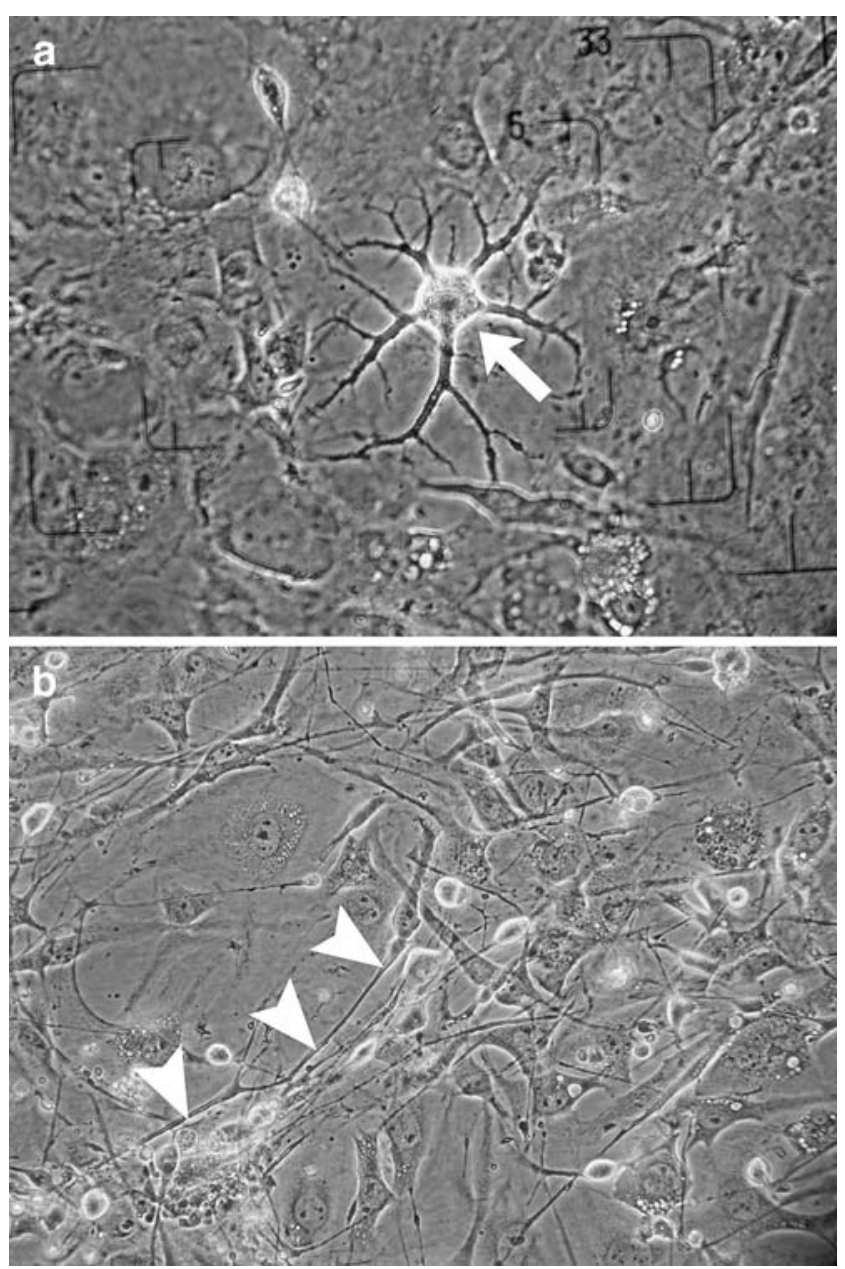

Fig. 6 STO feeder cells mimicking the morphology of a an oligodendrocyte (arrow) and b neuronal dendritic processes (arrowheads)

created so that the cell culture can be "passaged", that is, the population of cells can be subdivided for further growth, growth being inhibited if the cells are crowded together. However, and most importantly, the dissociation into single cells breaks down the cell-to-cell signaling that fosters stem cell differentiation. Thus, the routine passage of the cell population helps maintain the pluripotency of the ESC population over time. Species differences appear to exist in the ease with which ESC can be separated into a single cell or near single cell suspension.

The dissociation of primate ESC into single cell suspensions is a complicating factor in the continuous culture of these cell lines. Enzymatic and chemical dissociation of human or monkey ESC typically give replating efficiencies of less than $1 \%$ ([72]; personal communication, J.A. Thomson). In contrast, mESC are commonly dissociated by treatment with trypsin-EDTA for routine passage and maintenance of pluripotency, and their plating efficiencies are usually $20 \%$ or greater [15]. This also makes mESC more amenable to techniques basic to their use in creating genetically engineered mice, such as efficient colony-cloning and blastocyst injection [2]. Dissociation of the primary blastocyst or ICM culture used to establish monkey or human ES cell lines can be particularly troublesome in terms of cell survival and a careful physical dissociation (microdissection and micropipette aspiration) of the primary colony into small groups of cells is often performed [16, 17]. Again, in contrast, primary colony outgrowths of mouse ICMs or blastocysts are usually dissociated with trypsin-EDTA treatment in combination with mechanical manipulation to start off the secondary passage and establishment of the ES cell lines ([15]; personal communication, C.L. Stewart).

The sensitivity to cell-to-cell dissociation is even more pronounced in the epiblast cells of ungulates. Primary cultures of alkaline-phosphatase-positive, undifferentiated, ungulate epiblast cells prepared by the successive immunodissection, culture, and physical-dissection method [7, 20] are extremely sensitive to lysis by either physical manipulation, withdrawal of calcium, or exposure to trypsin-EDTA (unpublished observations; [8]). Primary cultures of pig epiblast cells, for example, will rupture and lyse after only 5 min exposure to $\mathrm{Ca}^{++} / \mathrm{Mg}^{++}$-free PBS with the cells completely disintegrating in 30-60 min. This inability to dissociate the ungulate epiblast cells from one another is a critical problem for the two reasons outlined above. First, the subdivision and expansion of the culture is rendered impossible, and second, but just as importantly, the cell-to-cell communication that precipitate differentiation of ESC is not possible to interrupt. Ungulate epiblast sensitivity to dissociation is so pronounced that, indeed, it can be used as a marker for the cells. That is, in stark contrast, colonial outgrowths of ungulate trophectoderm or visceral endoderm cells are very resistant to dissociation by PBS or trypsin-EDTA, and they are not prone to the rapid and catastrophic lysis that occurs with ungulate epiblast cells [48]. Further study to address this problem will probably be necessary for the successful establishment and manipulation of ungulate ESC. For example, we have noted that pig epiblast cells can be viably dissociated from each other if saline is used instead of PBS and if a rapid reattachment of the dissociated cells to a solid substrate is fostered (unpublished observations). It can only be hoped that the yet undiscovered cell culture conditions that will enable the growth and maintenance of ungulate ESC, or the induction of ungulate iPSC by ectopic pluripotency gene expression, will render changes in the cells that will make their subculture and passage at least as efficient as primate ESC.

Perhaps the most significant problem inherent to the establishment of ungulate ES cell lines is the inability to control the spontaneous differentiation of ungulate epiblast cells in culture (Fig. 5) [7, 20]. Microscopic observation of 
changes in cell morphology, a loss of alkaline phosphatase activity $[7,20,70]$, and the downregulation of pluripotency-associated transcription factors [71] indicate that differentiation events begin from 48-96 h post-plating of the pig epiblast cell mass. Larger initial colonies of epiblast cells tend to differentiate sooner and the smallest, consisting of 20 or fewer cells, usually become senescent and slowly die off ([7]; unpublished observations). Concurrent with these initial differentiation events, many of the resulting cell types now tolerate disaggregation by trypsin-EDTA [7, 20]. The LIF/gp130, bFGF2, NOG, activin A/NODAL pluripotency maintenance mechanisms appear to be either not operating or are insufficient for stopping this spontaneous differentiation in the ungulate ICM or epiblast primary culture (see Table 1) [7, 20, 71, 164]. However, further tests in alternative cell culture environments containing other growth factors, hormones, feedercells, or specific chemical inhibitors of differentiation signal pathways might yet be found to maintain the pluripotency of ungulate ESC [165, 166]. For example, a recent report claims that activation of the WNT signaling pathway using a specific inhibitor of GSK3B, 6-bromoindirubin-3'-oxime (BIO), maintains the pluripotency of both mouse and human ES cell lines in feeder-free culture conditions [124]. Although our preliminary tests of compounds related to $\mathrm{BIO}$, or mouse WNT3A and $\mathrm{LiCl}$, did not show significant inhibition of porcine epiblast cell differentiation, these types of amendments to the culture environment may eventually prove successful because concentration level, interactive combination, and timing may be critical parameters. Similarly, low oxygen culture conditions have reportedly improved the culture of hESC [167-169]. Although our initial tests of low $\mathrm{O}_{2}$ culture with porcine epiblast cells have proved disappointing (Table 1), it may ultimately prove useful since different species and cell types display different $\mathrm{O}_{2}$ optimums [170-172]. The maintenance of pluripotency is probably the most critical problem to be solved in establishing ungulate ES cell lines and should be a major focus of current research.

The optimal time for the initiation of blastocyst, ICM, or epiblast cell cultures for establishing ungulate ES cell lines is not known. Compared to mice and humans, the blastocysts of ungulates have an extended period of preimplantation development. The blastocyst of the pig, sheep, and cow first develops at approximately 6-7 days post-fertilization. The blastocyst then increases in size relatively slowly over the next few days of development as its spherical form increases in diameter. During this time there is probably only a modest increase in the number of epiblast cells in the ICM of the blastocyst compared to the increase in trophectoderm and visceral endoderm cells. At 11 to 12 days post-fertilization, depending on the ungulate species, the blastocyst elongates by the rapid growth of the trophectoderm and visceral endoderm to form a long, thin, filamentous blastocyst greater than $100 \mathrm{~mm}$ in length [6, 173]. The epiblast is exposed to the uterine environment during this preimplantation development by the loss of the overlaying layer of trophectoderm cells, or Rauber's layer, and the ICM is thereafter referred to as the embryonic disc [174]. Gastrulation, marked by the formation of the primitive streak in the embryonic disc, begins during this elongation phase and at this point mesoderm differentiation and migration from the epiblast is well underway ([175]; unpublished observations). Therefore, considering this unique preimplantation development, what developmental point is best for the isolation of pluripotent cells and the establishment of ungulate ES cell lines? The success rate for the establishment of pig ES-like cell cultures was decidedly better (12 [21\%] vs. none) from early hatched blastocysts than from late hatched blastocysts [28]. However, another report used in vivo pig blastocysts from day 5-6 to day $10-11$ of gestation and found that day 10-11 blastocyst yielded ES-like cell cultures. Few or none were propagated from day 5-6 embryos or day 11 blastocyst that had elongated [26]. In our experience, alkaline phosphatase-positive, pluripotent, epiblast cell cultures can be obtained from either the early pig blastocyst stage (7-8 days post-coitus) or from later stage embryonic discs (12-14 day post-coitus) where gastrulation has begun. No difference in the failure to inhibit differentiation of the epiblast cells or in the inability to propagate the epiblast cells was noted across these time points ([7]; unpublished observations). Thus, it is presently unclear whether epiblast cells from one stage of ungulate preimplantation development or another would be more efficient or required for the establishment of ES cells lines.

Although the age of ungulate blastocysts may turn out to be an important factor, the establishment of ungulate ES cell lines will definitely depend on in vitro culture conditions. For example, the nature and quality of feeder cells has been an important element in the establishment of mouse and primate ES cell lines. STO feeder cells were required for the survival of pig and bovine epiblast cells in primary culture $[7,20]$. Without feeder cell support cultures of primary pig epiblast cells fail to grow, and instead, senesced and die over a 10-14 day period (Fig. 2c). Similar, results were reported with feeder-independent, short-term, primary cultures of pig ICMs, with or without the addition of LIF to the medium [167]. It is probable that ungulate ES cell line establishment will therefore require feeders cells, at least in their initial culture, as has been true for the establishment of most mouse and primate ES cells lines. Although for both mouse and human ESC derivation STO feeder cells have been used successfully [14, 176], the use of primary or early secondary fetus-derived feeder cells is often thought to be of advantage. Primary feeder cell 
populations presumably supply different kinds and amounts of factors for the maintenance and growth of ES cells compared to STO feeder cells. By way of example, we recently found that the expression of serum-proteins from a porcine endoderm cell line was drastically effected by the use of CF-1 mouse-derived feeder cells compared to STO feeder cells (Fig. 4). The use of homologous primary feeder cells, e.g., bovine fibroblasts for bovine epiblast culture, would presumably remove the potential problem of specie specificities that exist with some cell ligand/cell receptor systems. However, primary fetal fibroblasts of the bovine and pig, which would be expected to produce LIF and bFGF, and most like several other cytokines, did not maintain bovine and pig epiblast cells, respectively, in the undifferentiated state in our experience (unpublished observation). Finally, some known or unknown cell-to cell interactions, or cytokines, or other soluble effector molecules in serumcontaining medium or expressed by the feeder cells, may be driving the differentiation of ungulate epiblast cells in culture. In any case, as more is learned about the molecular biology of pluripotency induction and maintenance for ESC, EGC, EpiSC, spermatogonial stem cells, somatic stem cells, and $\mathrm{PSSC}$, the in vitro conditions for ES cell line establishment from primary ungulate epiblast or somatic cells is becoming defined and testable. Thus, the prospects for the creation of ungulate ES cell lines is improving everyday.

Acknowledgements The authors thank Dr. W.M. Garrett for his kind help in preparing photographic figures and Dr. David Guthrie for his review and helpful editorial and scientific suggestions on the manuscript.

\section{References}

1. Evans, M. J., Notarianni, E., Laurie, S., \& Moor, R. M. (1990). Derivation and preliminary characterization of pluripotent cell lines from porcine and bovine blastocyst. Theriogenology, 33, 125-128.

2. Bradley, A. (1987). Production and analysis of chimaeric mice. In E. J. Robertson (Ed.), Teratocarcinomas and embryonic stem cells: a practical approach (pp. 113-151). Oxford: IRL.

3. Rideout, W. M., Wakayama, T., Wutz, A., et al. (2000). Generation of mice from wild-type and targeted ES cells by nuclear cloning. Nature Genetics, 24, 109-110.

4. Perrier, A. L., Tabar, V., Barberi, T., et al. (2004). Derivation of midbrain dopamine neurons from human embryonic stem cells. Proceedings of the National Academy of Sciences of the United States of America, 101, 12543-12548.

5. Takagi, Y., Takahashi, J., Saiki, H., et al. (2005). Dopaminergic neurons generated from monkey embryonic stem cells function in a Parkinson primate model. Journal of Clinical Investigation, 115, 102-109.

6. Carlson, B. M. (1981). Patten's foundations of embryology (4th ed.). New York: McGraw-Hill.

7. Talbot, N. C., Rexroad Jr, C. E., Pursel, V. G., Powell, A. M., \& Nel, N. D. (1993a). Culturing the epiblast cells of the pig blastocyst. In Vitro Cellular and Developmental Biology Animal, 29A, 543-554.
8. Talbot, N. C., \& Garrett, W. M. (2001). Ultrastructure of the embryonic stem cells of the 8-day pig blastocyst before and after in vitro manipulation: development of junctional apparatus and the lethal effects of PBS mediated cell-cell dissociation. Anatomical Record, 264, 101-113.

9. Vejlsted, M., Avery, B., Gjorret, J. O., \& Maddox-Hyttel, P. (2005). Effect of leukemia inhibitory factor (LIF) on in vitro produced bovine embryos and their outgrowth colonies. Molecular Reproduction and Development, 70, 445-454.

10. Brooks, F. A., \& Gardner, R. L. (1997). The origin and efficient derivation of embryonic stem cells in the mouse. Proceedings of the National Academy of Sciences of the United States of America, 94, 5709-5712.

11. Eistetter, H. R. (1989). Pluripotent embryonal stem cell lines can be established from disaggregated mouse morulae. Development, Growth \& Differentiation, 31, 275-282.

12. Strelchenko, N., Verlinsky, O., Kukharenko, V., \& Verlinsky, Y. (2004). Morula-derived human embryonic stem cells. Reproductive Biomedicine Online, 9, 623-629.

13. Evans, M. J., \& Kaufman, M. H. (1981). Establishment in culture of pluripotential cells from mouse embryos. Nature, 292, 154-156.

14. Martin, G. (1981). Isolation of a pluripotent cell line from early mouse embryos cultured in medium conditioned by teratocarcinoma stem cells. Proceedings of the National Academy of Sciences of the United States of America, 78, 7634-7638.

15. Robertson, E. J. (1987). Embryo-derived stem cell lines. In E. J. Robertson (Ed.), Teratocarcinomas and embryonic stem cells: a practical approach (pp. 71-112). Oxford: IRL.

16. Thomson, J. A., Kalishman, J., Golos, T. G., et al. (1995). Isolation of a primate embryonic stem cell line. Proceedings of the National Academy of Sciences of the United States of America, 92, 7844-7848.

17. Thomson, J. A., Itskovitz-Eldor, J., Shapiro, S. S., et al. (1998). Embryonic stem cell lines derived from human blastocysts. Science, 282, 1145-1147.

18. Reubinoff, B. E., Pera, M. F., Fong, C. Y., Trounson, A., \& Bongso, A. (2000). Embryonic stem cell lines from human blastocysts: somatic differentiation in vitro. Nature Biotechnology, 18, 399-404.

19. Lee, J. B., Lee, J. E., Park, J. H., et al. (2005). Establishment and maintenance of human embryonic stem cell lines on human feeder cells derived from uterine endometrium under serum-free condition. Biology of Reproduction, 72, 42-49.

20. Talbot, N. C., Powell, A. M., \& Rexroad Jr., C. E. (1995). In vitro pluripotency of epiblasts derived from bovine blastocysts. Molecular Reproduction and Development, 42, 35-52.

21. Notarianni, E., Laurie, S., Moor, R. M., \& Evans, M. J. (1990). Maintenance and differentiation in culture of pluripotential embryonic cell lines from pig blastocysts. Journal of Reproduction And Fertility. Supplement, 41, 51-56.

22. Notarianni, E., Galli, C., Laurie, S., Moor, R. M., \& Evans, M. J. (1991). Derivation of pluripotent, embryonic cell lines from the pig and sheep. Journal of Reproduction And Fertility. Supplement, 43, 255-260.

23. Piedrahita, J. A., Anderson, G. B., \& BonDurrant, R. H. (1990a). On the isolation of embryonic stem cells: comparative behavior of murine, porcine and ovine embryos. Theriogenology, 34, 879-901.

24. Piedrahita, J. A., Anderson, G. B., \& BonDurrant, R. H. (1990b). Influence of feeder layer type on the efficiency of isolation of porcine embryo-derived cell lines. Theriogenology, 34, 865-877.

25. Strojek, R., Reed, M. A., Hoover, J. L., \& Wagner, T. E. (1990). A method for cultivating morphologically undifferentiated embryonic stem cells from porcine blastocysts. Theriogenology, 33, 901-913.

26. Hochereau-de Reviers, M. T., \& Perreau, C. (1993). In vitro culture of embryonic disc cells from porcine blastocysts. Reproduction Nutrition Development, 33, 475-483. 
27. Wheeler, M. B. (1994). Development and validation of swine embryonic stem cells: a review. Reproduction, Fertility And Development, 6, 563-568.

28. Chen, L. R., Shiue, Y. L., Bertolini, L., Medrano, J. F., BonDurant, R. H., \& Anderson, G. B. (1999). Establishment of pluripotent cell lines from porcine preimplantation embryos. Theriogenology, 52, 195-212.

29. Li, M., Zhang, D., Hou, Y., Jiao, L., Zheng, X., \& Wang, W. H. (2003). Isolation and culture of embryonic stem cells from porcine blastocysts. Molecular Reproduction and Development, $65,429-434$.

30. Li, M., Ma, W., Hou, Y., Sun, X. F., Sun, Q. Y., \& Wang, W. H. (2004a). Improved isolation and culture of embryonic stem cells from Chinese miniature pig. Journal of Reproduction and Development, 50, 237-244.

31. Li, M., Li, Y. H., Hou, Y., Sun, X. F., Sun, Q., \& Wang, W. H. (2004b). Isolation and culture of pluripotent cells from in vitro produced porcine embryos. Zygote, 12, 43-48.

32. Shim, H., Gutierrez-Adan, A., Chen, L. R., BonDurant, R. H., Behboodi, E., \& Anderson, G. B. (1997). Isolation of pluripotent stem cells from cultured porcine primordial germ cells. Biology of Reproduction, 57, 1089-1095.

33. Mueller, S., Prelle, K., Rieger, N., et al. (1999). Chimeric pigs following blastocyst injection of transgenic porcine primordial germ cells. Molecular Reproduction and Development, 54, 244-254.

34. Tsung, H. C., Du, Z. W., Rui, R., et al. (2003). The culture and establishment of embryonic germ (EG) cell lines from Chinese mini swine. Cell Research, 13, 195-202.

35. Rui, R., Shim, H., Moyer, A. L., et al. (2004). Attempts to enhance production of porcine chimeras from embryonic germ cells and preimplantation embryos. Theriogenology, 61, 1225-1235.

36. Sims, M., \& First, N. L. (1994). Production of calves by transfer of nuclei from cultured inner cell mass cells. Proceedings of the National Academy of Sciences of the United States of America, 91, 6143-6147.

37. First, N. L., Sims, M. M., Park, S. P., \& Kent-First, M. J. (1994). Systems for production of calves from cultured bovine embryonic cells. Reproduction, Fertility and Development, 6, 553-562.

38. Cibelli, J. B., Stice, S. L., Golueke, P. J., et al. (1998). Transgenic bovine chimeric offspring produced from somatic cell-derived stem-like cells. Nature Biotechnology, 16, 642-646.

39. Iwasaki, S., Campbell, K. H., Galli, C., \& Akiyama, K. (2000). Production of live calves derived from embryonic stem-like cells aggregated with tetraploid embryos. Biology of Reproduction, 62, 470-475.

40. Mitalipova, M., Beyhan, Z., \& First, N. L. (2001). Pluripotency of bovine embryonic cell line derived from precompacting embryos. Cloning, 3, 59-67.

41. Saito, S., Sawai, K., Ugai, H., et al. (2003). Generation of cloned calves and transgenic chimeric embryos from bovine embryonic stem-like cells. Biochemical and Biophysical Research Cоттиnications, 309, 104-113.

42. Wang, G., Zhang, H., Zhao, Y., et al. (2005). Noggin and bFGF cooperate to maintain the pluripotency of human embryonic stem cells in the absence of feeder layers. Biochemical and Biophysical Research Communications, 330, 934-942.

43. Keefer, C. L., Karatzas, C. N., Lazaris-Karatzas, A., Gagnon, I., Poulin, , \& Downey, B. R. (1996). Isolation and maintenance of putative embryonic stem cells derived from Nigerian Dwarf goat embryos. Biology of Reproduction, 54, abstr. 462.

44. Kuhholzer, B., Baguisi, A., \& Overstrom, E. W. (2000). Longterm culture and characterization of goat primordial germ cells. Theriogenology, 53, 1071-1079.

45. Saito, S., Ugai, H., Sawai, K., et al. (2002). Isolation of embryonic stem-like cells from equine blastocysts and their differentiation in vitro. FEBS Letters, 531, 389-396.
46. Li, X., Zhou, S. G., Imreh, M. P., Ahrlund-Richter, L., \& Allen, W. R. (2006). Horse embryonic stem cell lines from the proliferation of inner cell mass cells. Stem Cells and Development, 15, 523-531.

47. Flechon, J. E., Laurie, S., \& Notarianni, E. (1995). Isolation and characterization of a feeder-dependent, porcine trophectoderm cell line obtained from a 9-day blastocyst. Placenta, 16, 643-658.

48. Talbot, N. C., Caperna, T. J., Edwards, J. L., Garrett, W., Wells, K. D., $\&$ Ealy, A. D. (2000). Bovine blastocyst-derived trophectoderm and endoderm cell cultures: interferon tau and transferrin expression as respective in vitro markers. Biology of Reproduction, 62, 235-247.

49. Shimada, A., Nakano, H., Takahashi, T., Imai, K., \& Hashizume, K. (2001). Isolation and characterization of a bovine blastocyst-derived trophoblastic cell line, BT-1: development of a culture system in the absence of feeder cell. Placenta, 22, 652-662.

50. Miyazaki, H., Imai, M., Hirayama, T., et al. (2002). Establishment of feeder-independent cloned caprine trophoblast cell line which expresses placental lactogen and interferon tau. Placenta, 23, 613-630.

51. Talbot, N. C., Caperna, T. J., Powell, A. M., Ealy, A. D., Blomberg, L. A., \& Garrett, W. M. (2005). Isolation and characterization of a bovine visceral endoderm cell line derived from a parthenogenetic blastocyst. In Vitro Cellular and Developmental Biology Animal, 41, 130-141.

52. Talbot, N. C., Paape, M., Sohn, E. J., \& Garrett, W. M. (2004). Macrophage population dynamics within fetal mouse fibroblast cultures derived from C57BL/6, CD-1, CF-1 mice and interleukin6 and granulocyte colony stimulating factor knockout mice. In Vitro Cellular and Developmental Biology Animal, 40, 196-210.

53. Thomson, J. A., Kalishman, J., Golos, T. G., Durning, M., Harris, C. P., \& Hearn, J. P. (1996). Pluripotent cell lines derived from common marmoset (Callithrix jacchus) blastocysts. Biology Of Reproduction, 55, 254-259.

54. Kato, Y., Tani, T., \& Tsunoda, Y. (2000). Cloning of calves from various somatic cell types of male and female adult, newborn and fetal cows. Journal of Reproduction and Fertility, 120, 231-237.

55. Wakayama, T., \& Yanagimachi, R. (2001). Mouse cloning with nucleus donor cells of different age and type. Molecular Reproduction and Development, 58, 376-383.

56. Tsunoda, Y., \& Kato, Y. (1998). Not only inner cell mass cell nuclei but also trophectoderm nuclei of mouse blastocysts have a developmental totipotency. Journal of Reproduction and Fertility, 113, 181-194.

57. Suda, Y., Suzuki, M., Ikawa, Y., \& Aizawa, S. (1987). Mouse embryonic stem cells exhibit indefinite proliferative potential. Journal of Cellular Physiology, 133, 197-201.

58. Amit, M., Carpenter, M. K., Inokuma, M. S., et al. (2000). Clonally derived human embryonic stem cell lines maintain pluripotency and proliferative potential for prolonged periods of culture. Developments in Biologicals, 227, 271-278.

59. Freshney, R. I. (1994). Culture of animal cells (3rd ed.). New York: Wiley-Liss.

60. Hubner, K., Fuhrmann, G., Christenson, L. K., et al. (2003). Derivation of oocytes from mouse embryonic stem cells. Science, 300, 1251-1256.

61. Geijsen, N., Horoschak, M., Kim, K., Gribnau, J., Eggan, K., \& Daley, G. Q. (2004). Derivation of embryonic germ cells and male gametes from embryonic stem cells. Nature, 427, 148-154.

62. Niwa, H., Miyazaki, J., \& Smith, A. G. (2000). Quantitative expression of Oct-3/4 defines differentiation, dedifferentiation or self-renewal of ES cells. Nature Genetics, 24, 372-376.

63. Tolkunova, E., Cavaleri, F., Eckardt, S., et al. (2006). The caudal-related protein $\mathrm{Cdx} 2$ promotes trophoblast differentiation of mouse ES cells. Stem Cells, 24, 139-144.

64. Nagy, A., Rossant, J., Nagy, R., Abramow-Newerly, W., \& Roder, J. C. (1993). Derivation of completely cell culture- 
derived mice from early-passage embryonic stem cells. Proceedings of the National Academy of Sciences of the United States of America, 90, 8424-8428.

65. Snodgrass, H. R., Schmitt, R. M., \& Bruyns, E. (1992). Embryonic stem cells and in vitro hematopoiesis. Journal of Cellular Biochemistry, 49, 225-230.

66. Brons, I. G., Smithers, L. E., Trotter, M. W., et al. (2007). Derivation of pluripotent epiblast stem cells from mammalian embryos. Nature, 448, 191-195.

67. Tesar, P. J., Chenoweth, J. G., Brook, F. A., et al. (2007). New cell lines from mouse epiblast share defining features with human embryonic stem cells. Nature, 448, 196-199.

68. Lovell-Badge, R. (2007). Many ways to pluripotency. Nature Biotechnology, 25, 1114-1116.

69. Smith, J. R., \& Whitney, R. G. (1980). Intraclonal variation in proliferative potential of human diploid fibroblasts: stochastic mechanism for cellular aging. Science, 207, 82-84.

70. Talbot, N. C., Rexroad Jr., C. E., Pursel, V. G., \& Powell, A. M. (1993b). Alkaline phosphatase staining of pig and sheep epiblast cells in culture. Molecular Reproduction and Development, 36, 139-147.

71. Blomberg, L. A., Schreier, L. L., \& Talbot, N. C. (2008). Expression analysis of pluripotency factors in the undifferentiated porcine inner cell mass and epiblast during in vitro culture. Molecular Reproduction and Development, 75(3), 450-463.

72. Thomson, J. A., \& Marshall, V. S. (1998). Primate embryonic stem cells. In R. A. Pedersen, \& G. P. Schatten (Eds.), Current topics in developmental biology (pp. 133-165). San Diego, CA: Academic.

73. Hogan, B., Beddington, R., Constantini, F., \& Lacy, E. (1994). Manipulating the mouse embryo p. 259. Plainview, NY: Cold Spring Harbor Laboratory and p. 409.

74. Eshkind, L., Tian, Q., Schmidt, A., Franke, W. W., Windoffer, R., \& Leube, R. E. (2002). Loss of desmoglein 2 suggests essential functions for early embryonic development and proliferation of embryonal stem cells. European Journal Of Cell Biology, 81, 592598.

75. Park, S. H., Park, S. H., Kook, M. C., Kim, E. Y., Park, S., \& Lim, J. H. (2004). Ultrastructure of human embryonic stem cells and spontaneous and retinoic acid-induced differentiating cells. Ultrastructural Pathology, 28, 229-238.

76. Nichols, J., Zevnik, B., Anastassiadis, K., et al. (1998). Formation of pluripotent stem cells in the mammalian embryo depends on the POU transcription factor Oct4. Cell, 95, 379-391.

77. Matsuda, T., Nakamura, T., Nakao, K., Arai, T., Katsuki, M., \& Heike, T. (1999). STAT3 activation is sufficient to maintain an undifferentiated state of mouse embryonic stem cells. EMBO Journal, 18, 4261-4269.

78. Ying, Q. L., Nichols, J., Chambers, I., \& Smith, A. (2003). BMP induction of Id proteins suppresses differentiation and sustains embryonic stem cell self-renewal in collaboration with STAT3. Cell, 115, 281-292.

79. Pauling, N. R., Wheadon, H., Bone, H. K., \& Welham, M. J. (2004). Regulation of embryonic stem cell self-renewal by phosphoinositide 3-kinase-dependent signaling. Journal of Biological Chemistry, 279, 48063-48070.

80. Cartwright, P., McLean, C., Sheppard, A., Rivett, D., Jones, K., \& Dalton, S. (2005). LIF/STAT3 controls ES cell self-renewal and pluripotency by a Myc-dependent mechanism. Development, $132,885-896$.

81. Henderson, J. K., Draper, J. S., Baillie, H. S., et al. (2002). Preimplantation human embryos and embryonic stem cells show comparable expression of stage-specific embryonic antigens. Stem Cells, 20, 329-337.

82. Nichols, J., Davidson, D., Taga, T., Yoshida, K., Chambers, I., \& Smith, A. (1996). Complementary tissue-specific expression of
LIF and LIF-receptor mRNAs in early mouse embryogenesis. Mechanisms of Development, 57, 123-131.

83. Geisert, R. D., Brookbank, J. W., Roberts, R. M., \& Bazer, F. W. (1982). Establishment of pregnancy in the pig. II. Cellular remodeling of the porcine blastocyst during elongation on day 12 of pregnancy. Biology of Reproduction, 27, 941-955.

84. Betteridge, K. J., \& Fléchon, J. E. (1988). The anatomy and physiology of pre-attachment bovine embryos. Theriogenology, 29, 155-187.

85. Gallicano, G. I. (2001). Composition, regulation, and function of the cytoskeleton in mammalian eggs and embryos. Frontiers in Bioscience, 6, D1089-D1108.

86. Hue, I., Renard, J. P., \& Viebahn, C. (2001). Brachyury is expressed in gastrulating bovine embryos well ahead of implantation. Development, Genes and Evolution, 211, 157-159.

87. Fléchon, J. E., Degrouard, J., \& Fléchon, B. (2004). Gastrulation events in the prestreak pig embryo: ultrastructure and cell markers. Genesis, 38, 13-25.

88. Blomberg, L. A., Garrett, W. M., Guillomot, M., et al. (2006). Transcriptome profiling of the tubular porcine conceptus identifies the differential regulation of growth and developmentally associated genes. Molecular Reproduction and Development, 73(12), 1491-1502.

89. Keefer, C. L., Pant, D., Blomberg, L., \& Talbot, N. C. (2007). Challenges and prospects for the establishment of embryonic stem cell lines of domesticated ungulates. Animal Reproduction Science, 98, 147-168.

90. Furue, M., Okamoto, T., Hayashi, Y., et al. (2005). Leukemia inhibitory factor as an anti-apoptotic mitogen for pluripotent mouse embryonic stem cells in a serum-free medium without feeder cells. In Vitro Cellular and Developmental Biology Animal, 41, 19-28.

91. Ludwig, T. E., Levenstein, M. E., Jones, J. M., et al. (2006). Derivation of human embryonic stem cells in defined conditions. Nature Biotechnology, 24, 185-187.

92. Starr, R., Novak, U., Willson, T. A., et al. (1997). Distinct roles for leukemia inhibitory factor receptor alpha-chain and gp130 in cell type-specific signal transduction. Journal of Biological Chemistry, 272, 19982-19986.

93. Yoshida, K., Chambers, I., Nichols, J., et al. (1994). Maintenance of the pluripotential phenotype of embryonic stem cells through direct activation of gp130 signalling pathways. Mechanisms of Development, 45, 163-171.

94. Zhang, J. G., Owczarek, C. M., Ward, L. D., et al. (1997). Evidence for the formation of a heterotrimeric complex of leukaemia inhibitory factor with its receptor subunits in solution. Biochemical Journal, 325, 693-700.

95. Akagi, T., Usuda, M., Matsuda, T., et al. (2005). Identification of zpf-57 as a downstream molecule of STAT3 and Oct-3/4 in embryonic stem cells. Biochemical and Biophysical Research Communications, 331, 23-30.

96. Li, Y., McClintock, J., Zhong, , Edenberg, H. J., Yoder, M. C., \& Chan, R. J. (2005). Murine embryonic stem cell differentiation is promoted by SOCS-3 and inhibited by the zinc finger transcription factor Klf4. Blood, 105, 635-637.

97. Jiang, J., Chan, Y. S., Loh, Y. H., et al. (2008). A core klf circuitry regulates self-renewal of embryonic stem cells. Nature Cell Biology, 10, 353-360.

98. Smith, A. G., Heath, J. K., Donaldson, D. D., et al. (1988). Inhibition of pluripotential embryonic stem cell differentiation by purified polypeptides. Nature, 336, 688-690.

99. Niwa, H., Burdon, T., Chambers, I., \& Smith, A. (1998). Selfrenewal of pluripotent embryonic stem cells is mediated via activation of STAT3. Genes and Development, 12, 2048-2060.

100. Ware, C. B., Horowitz, M. C., Renshaw, B. R., et al. (1995). Targeted disruption of the low-affinity leukemia inhibitory factor 
receptor gene causes placental, skeletal, neural and metabolic defects and results in perinatal death. Development, 121, 1283-1299.

101. Sendtner, M., Götz, R., Holtmann, B., Escary, J. L., et al. (1996). Cryptic physiological trophic support of motoneurons by LIF revealed by double gene targeting of CNTF and LIF. Current Biology, 6, 686-694.

102. Wånggren, K., Lalitkumar, P. G., Hambiliki, F., Ståbi, B., Gemzell-Danielsson, K., \& Stavreus-Evers, A. (2007). Leukaemia inhibitory factor receptor and gp130 in the human fallopian tube and endometrium before and after mifepristone treatment and in the human preimplantation embryo. Molecular Human Reproduction, 13, 391-397.

103. Dahéron, L., Opitz, S. L., Zaehres, H., et al. (2004). LIF/STAT3 signaling fails to maintain self-renewal of human embryonic stem cells. Stem Cells, 22, 770-778.

104. Humphrey, R. K., Beattie, G. M., Lopez, A. D., et al. (2004). Maintenance of pluripotency in human embryonic stem cells is STAT3 independent. Stem Cells, 22, 522-530.

105. Sumi, T., Fujimoto, Y., Nakatsuji, N., \& Suemori, H. (2004). STAT3 is dispensable for maintenance of self-renewal in nonhuman primate embryonic stem cells. Stem Cells, 22, 861-872.

106. Ginis, I., Luo, Y., Miura, T., et al. (2004). Differences between human and mouse embryonic stem cells. Developments in Biologicals, 269, 360-380.

107. Wei, C. L., Miura, T., Robson, P., et al. (2005). Transcriptome profiling of human and murine ESCs identifies divergent paths required to maintain the stem cell state. Stem Cells, 23, 166-185.

108. Vackova, I., Ungrova, A., \& Lopes, F. (2007). Putative embryonic stem cell lines from pig embryos. Journal of Reproduction and Development, 53, 1137-1149.

109. Eckert, J., \& Niemann, H. (1998). mRNA expression of leukaemia inhibitory factor (LIF) and its receptor subunits glycoprotein 130 and LIF-receptor-beta in bovine embryos derived in vitro or in vivo. Molecular Human Reproduction, 4, 957-965.

110. Rizos, D., Gutiérrez-Adán, A., Pérez-Garnelo, S., De La Fuente, J., Boland, M. P., \& Lonergan, P. (2003). Bovine embryo culture in the presence or absence of serum: implications for blastocyst development, cryotolerance, and messenger RNA expression. Biology of Reproduction, 68, 236-243.

111. Pucéat, M. (2007). TGFb in the differentiation of embryonic stem cells. Cardiovascular Research, 74, 256-261.

112. Attisano, L., \& Wrana, J. L. (2007). Signal transduction by the TGF-b superfamily. Science, 296, 1646-1647.

113. Besser, D. (2004). Expression of nodal, lefty-a, and lefty-B in undifferentiated human embryonic stem cells requires activation of Smad2/3. Journal of Biological Chemistry, 279, 45076-45084.

114. James, D., Levine, A. J., Besser, D., \& Hemmati-Brivanlou, A. (2005). TGF(beta)/activin/nodal signaling is necessary for the maintenance of pluripotency in human embryonic stem cells. Development, 132, 1273-1282

115. Xiao, L., Yuan, X., \& Sharkis, S. J. (2006). Activin A maintains self-renewal and regulates fibroblast growth factor, Wnt, and bone morphogenic protein pathways in human embryonic stem cells. Stem Cells, 24, 1476-1486.

116. Xu, R. H., Peck, R. M., Li, D. S., Feng, X., Ludwig, T., \& Thomson, J. A. (2005). Basic FGF and suppression of BMP signaling sustain undifferentiated proliferation of human ES cells. Natural Methods, 2, 185-190.

117. Wang, L., Schulz, T. C., Sherrer, E. S., et al. (2007). Self-renewal of human embryonic stem cells requires insulin-like growth factor-1 receptor and ERBB2 receptor signaling. Blood, 110, 4111-4119.

118. Bendall, S. C., Stewart, M. H., Menendez, P., et al. (2007). IGF and FGF cooperatively establish the regulatory stem cell niche of pluripotent human cells in vitro. Nature, 448, 1015-1023.
119. Katoh, M., \& Katoh, M. (2007). WNT signaling pathway and stem cell signaling network. Clinical Cancer Research, 12, 4042-4045.

120. Nusse, R. (2008). Wnt signaling and stem cell control. Cell Research, 18(5), 523 PMID, 18392048.

121. Pereira, L., Yi, F., \& Merrill, B. J. (2006). Repression of Nanog gene transcription by Tcf3 limits embryonic stem cell selfrenewal. Molecular And Cellular Biology, 26, 7479-7491.

122. He, T. C., Sparks, A. B., Rago, C., et al. (1998). Identification of c-MYC as a target of the APC pathway. Science, 281, 1509-1512.

123. Prowse, A. B. J., McQuade, L. R., Bryanot, K. J., Marcal, H., \& Gray, P. P. (2007). Identification of potential pluripotency determinants for human embryonic stem cells following proteomic analysis of human and mouse fibroblast conditioned media. Journal of Proteome Research, 6, 3796-3807.

124. Sato, N., Meijer, L., Skaltsounis, L., Greengard, P., \& Brivanlou, A. H. (2004). Maintenance of pluripotency in human and mouse embryonic stem cells through activation of Wnt signaling by a pharmacological GSK-3-specific inhibitor. Nature Medicine, 10, $55-63$.

125. Anton, R., Kestler, , \& Kuhl, M. (2007). b-catenin signaling contributes to stemness and regulates early differentiation in murine embryonic stem cells. FEBS Letters, 581, 5247-5254.

126. Dravid, G., Ye, Z., Hammond, H., et al. (2005). Defining the role of Wnt/b-catenin signaling in the survival, proliferation and selfrenewal of human embryonic stem cells. Stem Cells, 23, 14891501.

127. Rodda, D. J., Chew, J. L., Lim, L. H., et al. (2005). Transcriptional regulation of Nanog by OCT4 and SOX2. Journal of Biological Chemistry, 280, 24731-24737.

128. Boyer, L. A., Mathur, D., \& Jaenisch, R. (2006a). Molecular control of pluripotency. Current Opinion in Genetics and Development, 16, 455-462.

129. Loh, Y. H., Wu, Q., Chew, J. L., et al. (2006). The Oct4 and Nanog transcription network regulates pluripotency in mouse embryonic stem cells. Nature Genetics, 38, 431-440.

130. Babaie, Y., Herwig, R., Greber, B., et al. (2007). Analysis of OCT4 dependent transcriptional networks regulating self renewal and pluripotency in human embryonic stems cells. Stem Cells, 25 (2), 500-510.

131. Ivanova, N., Dobrin, R., Lu, R., et al. (2006). Dissecting selfrenewal in stem cells with RNA interference. Nature, 442, 533-538.

132. Cowan, C. A., Atienza, J., Melton, D. A., \& Eggan, K. (2005). Nuclear reprogramming of somatic cells after fusion with human embryonic stem cells. Science, 309, 1369-1373.

133. Azuara, V., Perry, P., Sauer, S., Spivakov, M., et al. (2006). Chromatin signatures of pluripotent cell lines. Nature Cell Biology, 8, 532-538.

134. Meshorer, E., Yellajoshula, D., George, E., Scambler, P. J., Brown, D. T., \& Misteli, T. (2006). Hyperdynamic plasticity of chromatin proteins in pluripotent embryonic stem cells. Development Cell, 10, 105-116.

135. Wernig, M., Meissner, A., Foreman, R., et al. (2007). In vitro reprogramming of fibroblasts into a pluripotent ES-cell-like state. Nature, 448, 318-324.

136. Mikkelsen, T. S., Ku, M., Jaffe, D. B., et al. (2007). Genomewide maps of chromatin state in pluripotent and lineagecommitted cells. Nature, 448, 553-560.

137. Ringrose, L., \& Paro, R. (2004). Epigenetic regulation of cellular memory by the Polycomb and Trithorax group proteins. Annual Review of Genetics, 38, 413-443.

138. Schuettengruber, B., Chourrout, D., Vevoort, M., Leblanc, B., \& Cavalli, G. (2007). Genome regulation by Polycomb and Trithorax proteins. Cell, 128, 735-745.

139. Trojer, P., \& Reinberg, D. (2006). Histone lysine demethylases and their impact on epigenetics. Cell, 125, 213-217. 
140. Boyer, L. A., Plath, K., Zeitlinger, J., et al. (2006b). Polycomb complexes repress developmental regulators in murine embryonic stem cells. Nature, 441, 349-353.

141. Lee, T. I., Jenner, R. G., Boyer, L. A., et al. (2006). Control of developmental regulators by Polycomb in human embryonic stem cells. Cell, 125, 301-313.

142. Cao, R., \& Zhang, Y. (2004). The functions of E(Z)/EZH2mediated methylation of lysine 27 in histone H3. Current Opinion in Genetics and Development, 14, 155-164.

143. Wysocka, J., Swigut, T., Milne, T. A., et al. (2005). WDR5 associates with histone He methylated at $\mathrm{K} 4$ and is essential for $\mathrm{H} 3$ K4 methylation and vertebrate development. Cell, 121, 859-872.

144. Francis, N. J., Kinston, R. E., \& Woodcock, C. L. (2004). Chromatin compaction by a Polycomb group protein complex. Science, 306, 1574-1577.

145. Kim, T. H., Barrera, L. O., Zheng, M., et al. (2005). A highresolution map of active promoters in the human genome. Nature, 436, 876-880.

146. Bracken, A. P., Dietrich, N., Pasini, D., Hansen, K. H., \& Helin, K. (2006). Genome-wide mapping of Polycomb target genes unravels their roles in cell fate transitions. Genes Development, 20, 11231136.

147. O'Carroll, D., Erhardt, S., Pagani, M., Barton, S. C., Surani, M. A., \& Jenuwein, T. (2001). The Polycomb-group gene Ezh2 is required for early mouse development. Molecular and Cellular Biology, 21, 4330-4336.

148. Collas, P., Noer, A., \& Timoskainen, S. (2007). Programming the genome in embryonic and somatic stem cells. Journal of Cellular and Molecular Medicine, 11, 602-620.

149. Jackson, M., Kassowska, A., Gilbert, N., et al. (2004). Severe global DNA hypomethylation blocks differentiation and induces histone hyperacetylation in embryonic stem cells. Molecular and Cellular Biology, 24, 8862-8871.

150. Bibikova, M., Chudin, E., Wu, B., et al. (2006). Human embryonic stem cells have a unique epigenetic signature. Genome Research, 16, 1075-1083.

151. Bernstein, B. E., Mikkelsen, T. S., Xie, X., et al. (2006). A bivalent chromatin structure marks key developmental genes in embryonic stem cells. Cell, 125, 315-326.

152. Takahashi, K., \& Yamanaka, S. (2006). Induction of pluripotent stem cells from mouse embryonic and adult fibroblast cultures by defined factors. Cell, 126, 663-676.

153. Stadtfeld, M., Maherali, N., Breault, D. T., \& Hoechedlinger, K. (2008). Defining molecular cornerstones during fibroblast to iPS cell reprogramming in mouse. Cell Stem Cell, 2, 1-11.

154. Takahashi, K., Tanabe, K., Ohnuki, M., et al. (2007). Induction of pluripotent stem cells from adult human fibroblasts by defined factors. Cell, 131, 861-872.

155. Nakagawa, M., Koyanagi, M., Tanabe, K., et al. (2008). Generation of induced pluripotent stem cells without Myc from mouse and human fibroblasts. Nature Biotechnology, 26, 101-106.

156. Wernig, M., Meissner, A., Cassady, J. P., \& Jaenisch, (2008). CMyc is dispensable for direct reprogramming of mouse fibroblasts. Cell Stem Cell, 2, 10-12.

157. McWhir, J., Schnieke, A. E., Ansell, R., et al. (1996). Selective ablation of differentiated cells permits isolation of embryonic stem cell lines from murine embryos with a non-permissive genetic background. Nature Genetics, 14, 223-226.

158. Nichols, J., Chambers, I., Taga, T., \& Smith, A. (2001). Physiological rationale for responsiveness of mouse embryonic stem cells to gp130 cytokines. Development, 128, 2333-2339.

159. Jaenisch, R., \& Young, R. (2008). Stem cells, the molecular circuitry of pluripotency and nuclear reprogramming. Cell, 132, 567-582.

160. Talbot, N. C., Blomberg, L. A., Mahmood, A., Caperna, T. J., \& Garrett, W. M. (2007). Isolation and characterization of porcine visceral endoderm cell lines derived from in vivo 11-day blastocysts. In Vitro Cellular And Developmental Biology Animal, 43, 72-86.

161. van Eijk, M. J., van Rooijen, M. A., Modina, S., et al. (1999). Molecular cloning, genetic mapping, and developmental expression of bovine POU5F1. Biology of Reproduction, 60, 1093-1103.

162. Kirchhof, N., Carnwath, J. W., Lemme, E., Anastassiadis, K., Scholer, H., \& Niemann, H. (2000). Expression pattern of Oct-4 in preimplantation embryos of different species. Biology of Reproduction, 63, 1698-1705.

163. Gibson-D'Ambrosio, R. E., Samuel, M., Chang, C. C., Trosko, J. E., \& D'Ambrosio, S. M. (1987). Characteristics of long-term human epithelial cell cultures derived from normal human fetal kidney. In Vitro Cellular and Developmental Biology, 23, 279287.

164. Moore, K., \& Piedrahita, J. A. (1997). The effects of human leukemia inhibitory factor (hLIF) and culture medium on in vitro differentiation of cultured porcine inner cell mass (pICM). In Vitro Cellular and Developmental Biology Animal, 33, 62-71.

165. Piedrahita, J. A., Weaks, R., Petrescu, A., Shrode, T. W., Derr, J. N., \& Womack, J. E. (1997). Genetic characterization of the bovine leukaemia inhibitory factor (LIF) gene: isolation and sequencing, chromosome assignment and microsatellite analysis. Animal Genetics, 28, 14-20.

166. Spotter, A., Drogemuller, C., Kuiper, H., Brenig, B., Leeb, T., \& Distl, O. (2001). Molecular characterization and chromosome assignment of the porcine gene for leukemia inhibitory factor LIF. Cytogenetics and Cell Genetics, 93, 87-90.

167. Ezashi, T., Das, P., \& Roberts, R. M. (2005). Low O2 tensions and the prevention of differentiation of hES cells. Proceedings of the National Academy of Sciences of the United States of America, 102, 4783-4788.

168. Peura, T., Bosman, A., \& Stojanov, T. (2005). Improved growth of human embryonic stem cells in a reduced oxygen atmosphere. Reproduction, Fertility and Development, 17, 238-239.

169. Ording, C. J., Josephson, H. K., \& Auerbach, J. M. (2006). Effects of reduced oxygen tension on HUES-7 human embryonic stem cells. ATCC Connection, 25, 1-5.

170. Taylor, W. G., \& Camalier, R. F. (1982). Modulation of epithelial cell proliferation in culture by dissolved oxygen. Journal of Cellular Physiology, 111, 21-27.

171. Zagorski, Z., Grossler, B., \& Naumann, G. O. (1989). Effect of low oxygen tension on the growth of bovine corneal endothelial cells in vitro. Ophthalmic Research, 21, 440-442.

172. Akeo, K., Nagaski, K., Tanaka, Y., Curran, S. A., \& Dorey, C. K. (1992). Comparison of effects of oxygen and antioxidative enzymes on cell growth between retinal pigment epithelial cells and vascular endothelial cells in vitro. Opthalmic Research, 24, 357-364.

173. Chang, M. C. (1952). Development of bovine blastocyst with a note on implantation. Anatomical Record, 113, 143-161.

174. Stroband, H. W. J., Taverne, N., \& Bogaard, M. V. D. (1984). The pig blastocyst: its ultrastructure and the uptake of protein macromolecules. Cell Tissue Research, 235, 347-356.

175. Guillomot, M., Turbe, A., Hue, I., \& Renard, J. P. (2004). Staging of ovine embryos and expression of the T-box genes Brachyury and Eomesodermin around gastrulation. Reproduction, 127, 491-501.

176. Park, J. H., Kim, S. J., Oh, E. J., et al. (2003). Establishment and maintenance of human embryonic stem cells on STO, a permanently growing cell line. Biology of Reproduction, 69, 2007-2014.

177. Talbot, N. C., \& Paape, M. J. (1996). Continuous culture of pig tissue-derived macrophages. Methods in Cell Science, 18, 315327. 